Journal Pre-proof

The Transmission Mechanism of Credit Support Policies in the Euro Area

Jef Boeckx, Maite De Sola Perea, Gert Peersman

PII: S0014-2921(20)30035-0

DOI: https://doi.org/10.1016/j.euroecorev.2020.103403

Reference: EER 103403

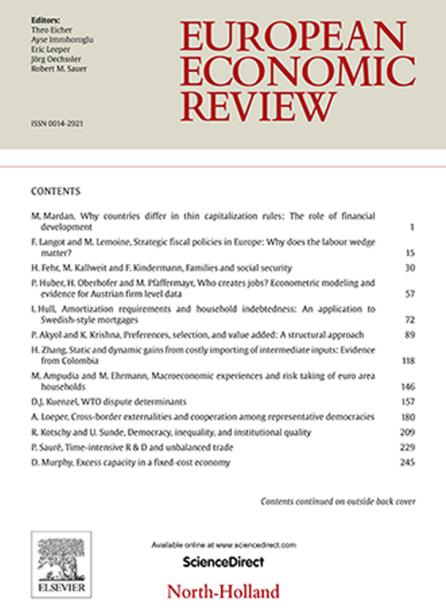

To appear in:

European Economic Review

Received date: $\quad 16$ March 2018

Accepted date: $\quad 4$ February 2020

Please cite this article as: Jef Boeckx, Maite De Sola Perea, Gert Peersman, The Transmission Mechanism of Credit Support Policies in the Euro Area, European Economic Review (2020), doi: https://doi.org/10.1016/j.euroecorev.2020.103403

This is a PDF file of an article that has undergone enhancements after acceptance, such as the addition of a cover page and metadata, and formatting for readability, but it is not yet the definitive version of record. This version will undergo additional copyediting, typesetting and review before it is published in its final form, but we are providing this version to give early visibility of the article. Please note that, during the production process, errors may be discovered which could affect the content, and all legal disclaimers that apply to the journal pertain.

(C) 2020 Published by Elsevier B.V. 


\title{
The Transmission Mechanism of Credit Support Policies in the Euro Area*
}

\author{
Jef Boeckx \\ National Bank of Belgium
}

\author{
Maite De Sola Perea \\ National Bank of Belgium
}

\author{
Gert Peersman \\ Ghent University
}

\begin{abstract}
We use an original monthly dataset of 131 banks to examine the effectiveness and transmission mechanism of the Eurosystem's credit support policies in the wake of the banking and sovereign debt crisis. First, we show that these policies were indeed succesful in stimulating the credit flow of banks to the private sector. Second, we find support for the "bank lending view" of monetary transmission. Specifically, the policies had a greater impact on loan supply of banks that were more constrained to obtain unsecured external funding, i.e. small banks (size effect), banks with less liquid balance sheets (liquidity effect), banks that depended more on wholesale funding (retail effect) and low-capitalized banks (capital effect). The role of bank capital was, however, ambiguous. Besides the above favorable direct effect on loan supply, lower levels of bank capitalization at the same time mitigated the size, retail and liquidity effects of the policies. The drag on the other channels was even dominant, i.e. better capitalized banks responded on average more to the credit support policies of the Eurosystem as a result of more favourable size, retail and liquidity effects.
\end{abstract}

JEL classification: E51, E52, E58, G01, G21

Keywords: unconventional monetary policy, bank lending, monetary transmission mechanism

\footnotetext{
${ }^{*}$ We are grateful to two anonymous referees, Luca Benati, Matteo Ciccarelli, Michele Lenza, participants at the NBB Conference on "The Transmission Mechanism of New and Traditional Instruments of Monetary and Macroprudential Policy" and the Eurosystem's "4th Research Workshop of the MPC Task-Force on Banking Analysis" for useful comments. The views expressed in this paper are those of the authors and do not necessarily reflect those of the National Bank of Belgium or the Eurosystem.
} 


\section{Introduction}

In the wake of the banking and sovereign debt crises, the Eurosystem has used several unpreceded monetary policy tools in response to the impairment and fragmentation of financial markets. A range of these measures made ample liquidity available to the banking system in order to compensate for the lack of market funding possibilities and to enhance the flow of credit to households and firms above and beyond what could be achieved through reductions in policy interest rates alone. The Eurosystem, for example, shifted from a variable rate tender to a fixed rate tender with full allotment, provided liquidity to banks at longer maturities, enlarged the pool of collateral accepted for refinancing operations, implemented a series of targeted operations at attractive conditions (TLTRO) and conducted outright purchases of covered bonds and asset-backed securities. Taken together, these measures are often called Enhanced Credit Support Policies (Trichet, 2009) or Credit Easing Policies (Draghi, 2015). ${ }^{1}$

A natural question that arises is whether these policies have indeed been effective in stimulating the credit flow of banks to the private sector and, if so, what were the exact transmission mechanisms. Both questions are addressed in this paper. To do so, we have put together an original monthly dataset of 131 individual euro area banks by merging different sources of data. In particular, we use two proprietary databases of monetary financial institutions data compiled by the Eurosystem: the individual balance sheet items (IBSI) database, which is used to construct the aggregate monetary and credit statistics of the euro area (e.g. M3), and the individual interest rate (IMIR) database of lending and deposit rates, which is compiled from the monetary financial institutions monthly interest rate surveys. These datasets are merged with a third source of data, i.e. SNL Financial, which contains several other balance sheet indicators for a subset of the banks included in the Eurosystem datasets.

The analysis proceeds in two steps. In a first step, we examine whether the credit easing policies have been effective in influencing bank lending behavior between the onset of the financial crisis and the start of the Expanded Asset Purchase Programme, i.e. over the sample period 2007M7-2014M12. ${ }^{2}$ More precisely, we apply Jordà's (2005) local projection

\footnotetext{
${ }^{1}$ Besides these policies, the Eurosystem has also implemented several unconventional measures that were rather aimed at stabilizing sovereign debt markets and further reducing long-term interest rates, for example the Securities Markets Programme, Outright Monetary Transactions Programme and the Expanded Asset Purchase Programme.

${ }^{2}$ The Expanded Asset Purchase Programme is not included in the estimations because the method that we use to identify exogenous credit easing shocks, i.e. the Boeckx et al. (2017) approach, is not appropriate for the period since the start of the programme. Specifically, the volumes of asset purchases are anticipated
} 
methods in a panel setting to estimate the dynamic effects of exogenous policy induced shocks to the balance sheet of the Eurosystem that are unrelated to conventional shifts in the policy rate. These shocks are borrowed from Boeckx et al. (2017). We find that expansionary credit policies lowered bank lending interest rates charged to the private sector, while the volume of bank lending increased significantly. The unconventional credit support measures have thus been successful in boosting credit to the non-financial private sector.

In a second step, we investigate the transmission mechanism in more detail. Specifically, in the spirit of Kashyap and Stein (1995; 2000), we explore whether there were important differences in the way that banks with varying characteristics responded to credit support policies. We test for the existence of four possible channels, which are all related to the conventional "bank lending view" of monetary transmission. The intuition of the empirical exercise can be motivated as follows: in an environment where financial markets are impaired, banks have more difficulties to raise external funds for their lending activities if they i) have greater asymmetric information problems, i.e. they are smaller, ii) have less liquid balance sheets, iii) depend more on the unsecured wholesale market to fund their lending activities and iv) are less well-capitalized. Accordingly, policies that enhance the access to central bank liquidity and relax the conditions to obtain such liquidity, should also primarily shift the loan supply schedules of these banks. The advantage of our local projection panel approach in this context is threefold. First, we can consider all these effects simultaneously, rather than the pairwise comparisons that are typically used in the existing literature (i.e. splitting the sample in two groups based on a specific bank characteristic). Since bank characteristics are correlated, this is important. Second, it allows us to consider the state of the bank at the moment that the shocks occurred, rather than relying on the averages of the bank characteristics over the whole sample period. This is also important because banks' balance sheet characteristics have evolved over the sample period, e.g. as a result of recapitalizations. Third, it allows to analyze the role of the interaction of balance sheet characteristics, which turns out to be important to understand the transmission mechanism.

The empirical evidence shows that the credit support policies have indeed stimulated the loan supply of small banks ( size effect), banks with less liquid balance sheets (liquidity effect), banks with a lower degree of retail funding (retail effect) and less well-capitalized banks (capital effect) significantly more than other banks, four features that are consistent

long time before the actual purchases, while the programme can also be considered as a monetary policy regime shift. 
with the "bank lending view". The role of bank capital was, however, ambiguous and turned out to be nonlinear. Besides the favorable direct capital effect on loan supply, lower levels of bank capitalization appear to have mitigated the size, retail and liquidity effects of credit support policies on bank lending. Put differently, higher capital ratios of banks seem to have dampened the impact of credit easing on loan supply via the above capital effect, but amplified the effectiveness of the size, retail and liquidity effects to stimulate bank lending. Overall, we find that the latter amplification mechanism has been dominant, i.e. better capitalized banks have on average responded more to the credit policies of the Eurosystem than low-capitalized banks. Noticeably, this result is almost fully driven by a weak response of low-capitalized banks that were not stimulated via the three other channels.

These results can be related to a growing number of studies that have analyzed the impact of monetary policy measures on credit supply since the onset of the financial crisis. Specifically, de Haan et al. (2016) find that shocks in wholesale funding have had a stronger impact on lending activities of large banks, which are typically more dependent on wholesale funding, as well as banks with large exposure to government bonds. They conclude that central bank liquidity provision may be effective because it can offset the impact of wholesale funding shocks. Andrade et al. (2015) find that the three-year LTROs in 2011-2012 had a positive impact on banks' supply of credit to firms, while financially constrained banks benefited most from the program. Furthermore, Boeckx et al. (2017) find that the effects of the Eurosystem's credit support policies on output across euro area countries were positively correlated with the degree of capitalization of the national banking sector during the financial crisis. Altavilla et al. (2016) arrive to similar conclusion using individual bank data, i.e. they document a stronger pass-through of unconventional monetary policies to lending rates of banks with a strong capital position. ${ }^{3}$ They find that this is also the case for banks with a high level of non-performing loans, or a high share of sovereign exposure. ${ }^{4}$ Our study distinguishes itself in several ways from these studies. First, we analyze the impact on both bank lending rates and the volume of lending. Second, we do not focus on one specific policy measure or event, but estimate the dynamic effects of a generic series of exogenous credit easing policy shocks. Third, we consider the role of several bank characteristics simultaneously, and take into account

\footnotetext{
${ }^{3}$ Holton and Rodriguez d'Acri (2015) find the opposite result, with banks with higher capital showing lower pass-through of changes in interest rates, though they explain this by considering that other variables may be capturing the underlying capital effect (i.e. degree of risk of a bank), or by the impact of recapitalizations during the crisis.

${ }^{4}$ The study of Altavilla et al. (2016), which has been conducted and written simultaneously with our study, also uses the Eurosystem's IMIR database.
} 
that these characteristics may vary over the sample period. Most importantly, we show that nonlinearities, in particular a nonlinear role of bank capital for other transmission mechanisms, are key for the effectiveness of credit support policies.

The results of this paper also relates to the literature on the bank lending and the bank capital channel of conventional monetary policy. In particular, Kashyap and Stein (1995; 2000) and Kishan and Opiela (2000; 2006), amongst others, find that smaller banks, banks with less liquid balance sheets, and low-capitalized banks react more strongly to a conventional monetary policy shock. We find similar channels for unconventional credit support policies. Furthermore, Van den Heuvel (2007) argues that the role of bank capital may be nonlinear for the transmission of conventional monetary policy, i.e. poorly capitalized banks are expected to react more to changes in interest rates, at least if their capital position is above a certain threshold. In contrast, when banks have very low capital positions or fear to fall below the threshold in the future, they might not react to a monetary policy change. We confirm the existence of such a nonlinearity for credit easing policies.

The remaining of the paper is structured as follows. In the next section, we describe the empirical approach, the monthly panel dataset of individual banks that we have collected for this study, the type of policy shocks that we consider, and the results of the overall effectiveness of credit support policies. Section 3 investigates the transmission mechanisms, while section 4 concludes and discusses some policy implications.

\section{Effectiveness of Credit Support Policies}

\subsection{Estimation method}

In this section, we explore whether the credit support policies of the Eurosystem have been effective in stimulating the flow of bank credit to the private sector. More precisely, we estimate the dynamic effects of such policies on the volume of bank lending to households and firms, as well as the corresponding lending rates. To do this, we use Jordà's (2005) local projection method for estimating impulse responses in a panel setting. Using local projections has several advantages for our purposes. First, in contrast to conventional panel estimation methods, this approach estimates the effects of policy shocks at different horizons, which is very convenient to examine the timing and dynamics of the effects of policy measures. Second, in contrast to e.g. structural VARs, it is easy to allow the impulse responses to be dependent on several (time-varying) bank characteristics simultaneously 
and to accommodate nonlinearities, which is what we will do in the next section. On the other hand, a disadvantage of this method is that sometimes quite erratic patterns are found for the dynamic effects because of a loss of efficiency, particularly at longer horizons, while the standard errors of the estimates are typically larger. For example, Monte Carlo simulations in Kilian and Kim (2011) show that structural impulse responses estimated with local projections methods tend to have higher bias, larger variance and lower coverage accuracy of confidence intervals in small samples compared to VAR estimations. These caveats should be taken into account when interpreting the results.

For each horizon, we estimate the following linear panel regression model:

$$
Z_{i, t+h}=\alpha_{i, h}+\delta_{i, h}(L) Z_{i, t}+\rho_{i, h}(L) X_{t}+\theta_{h} M P s h o c k_{t}+\varepsilon_{i, t+h}
$$

where $Z_{i, t+h}$ is respectively the volume of lending and lending rate of bank $i$ at horizon $h$, $\alpha_{i, h}$ are bank-specific fixed-effects, $X_{t}$ is a vector of control variables, $\delta_{i, h}(L)$ and $\rho_{i, h}(L)$ are bank-specific polynomials in the lag operator $L$, while $M P s h o c k_{t}$ represents the credit support policy shocks. Accordingly, $\theta_{h}$ is the estimated response of $Z$ at horizon $h$ to the policy shock at time $t$, which can be estimated with the Pooled Mean Group (PMG) estimator as described in Pesaran et al. (1999).

For a description of the dataset of individual bank lending rates and the volume of lending, and the credit support policy shocks, we refer to respectively section 2.2 and 2.3 . The set of (common) control variables that we include in all the estimations throughout this paper are i) the log of seasonally adjusted real GDP, ii) the log of seasonally adjusted HICP, iii) the log of central bank total assets, iv) the level of financial stress as measured by the Composite Indicator of Systematic Stress (CISS), v) the main refinancing operations (MRO) policy rate, vi) the spread between EONIA and the MRO-rate, and vii) respectively the euro area aggregate volume of lending and the lending rate. These variables should capture the main macroeconomic, financial and monetary policy fluctuations in the euro area during the sample period that may influence lending behavior of individual banks. Except for the aggregate volume of lending and lending rate, these are the variables of the benchmark VAR model of Boeckx et al. (2017) that we use to estimate the shocks. ${ }^{5}$ As a robustness check, we also systematically show results for estimations that include two additional (country-specific) control variables: the unemployment rate and the volume of debt security issuance by firms. Overall, the results are not very sensitive to the choice of the control variables. This also applies to the number of lags. In line with the VAR

\footnotetext{
${ }^{5}$ The series are obtained from Datastream and the ECB's Statistical Data Warehouse. For more details on the way they have been constructed, we refer to Boeckx et al. (2017).
} 
model, we set $L=3$ in all estimations. In fact, likelihood ratio tests suggest that less lags suffice for most estimations (i.e. typically $L=1$ ) . Results are, however, similar when we assume $L=1$ or $L=2$.

\subsection{Panel dataset of bank lending activities}

The dataset that we use to examine the pass-through of credit support policies has been collected by merging different sources of data. Specifically, we use two proprietary databases compiled by the Eurosystem. For the volume of lending to households and firms (non-financial corporations), we use the individual balance sheet items (IBSI) database, which contains 29 balance sheet indicators for a sample of 281 euro area monetary financial institutions (MFIs). These bank level data, collected at a monthly frequency, account for approximately $70 \%$ of total assets of the euro area banking sector, and follow the same template and definitions as those used by the Eurosystem to construct the aggregate euro area money and credit data (e.g. M3). The IBSI database includes end-of-month outstanding amounts and monthly transactions, i.e. the change in outstanding amounts corrected for non-economic factors (e.g. reclassifications, revaluations and other effects). ${ }^{6}$ Based on the outstanding amounts and monthly transactions, we construct chain-linked multiplicative notional stocks for the volume of lending to households and non-financial corporations according to the ECB methodology. ${ }^{7}$ Prior to the estimations, we have also conducted a double cleaning procedure on the data. In a first step, using publicly available information (including annual reports of financial institutions and websites), we corrected movements in flows when they did not adequately reflect the true transactions to avoid spurious movements in banks balance sheets (e.g. mergers and acquisitions were not always reflected appropriately in the data). In a second step, we subjected the data to outlier correction, by replacing monthly growth rates exceeding a threshold, which corresponds to the median plus or minus five interquartile ranges (calculated for all banks in the previous 12 months) by that threshold. ${ }^{8}$ The new monthly growth rate is then used to re-calculate the series of notional stocks. Finally, we apply a seasonal adjustment method to the notional stock series.

For the individual bank lending interest rates, we use the Eurosystem's individual monetary and financial institutions interest rate (IMIR) database, which contains monthly

\footnotetext{
${ }^{6}$ Sales and securitisations are not systematically taken into account for the calculation of the transactions, nor for the outstanding amounts. This is a caveat when using the dataset, in particular for the data on lending to the non-financial private sector.

${ }^{7}$ For a detailed explanation of this methodology, see ECB (2012) and Colangelo and Lenza (2013).

${ }^{8}$ Overall, about $16 \%$ of the observations have been cleaned based on this procedure.
} 
data on interest rates of new lending (and deposits) collected via the MIR survey. The IMIR database covers a large subsample of the IBSI banks, i.e. lending rates of 223 banks. For each bank, we computed a weighted aggregate interest rate series for lending to households for house purchases and to non-financial corporations. ${ }^{9}$ The interest rate series have also been subject to outlier correction. We considered that a rate charged by a bank in a specific month is an outlier when it is more than 75 basis points higher (or lower) than the rates charged in both the previous and subsequent month. These outliers have been replaced by the average of the rates charged in the previous and subsequent month.

The IBSI and IMIR data are based on a residential definition of the banks operating in each country. They refer to non-consolidated data, and hence include subsidiaries of foreign-owned banks. The panel is unbalanced as the time series start when the bank is created and/or the country has joined the euro area (if relevant), and are discontinued after mergers and failures.

The final dataset used in this paper covers a sample of 131 banks operating in the 19 euro area countries, with observations from August 2007 to October 2015 (though exact data of start and end of the series depend on the bank). Overall, we have more than 10,000 monthly observations for the estimations. The reason for the lower number of banks compared to the source dataset is the availability of the bank characteristics that will be used in section 3, for which also data from SNL Financial are used. The latter database contains consolidated and unconsolidated balance sheet and regulatory data from banks' public reports for fewer banks than the IBSI and IMIR databases. Moreover, we have dropped a number of banks prior to the estimations due to the presence of considerable noise in the series, the lack of significance for our analysis (e.g. no or very low volume of lending to the retail sector) or frequent gaps in the series.

The sample of banks used in the analysis represents $37 \%$ of total assets of the euro area banking sector, and $43 \%$ of the lending to non-financial corporations and households in October 2015. Table 1 shows the distribution and representativeness of the sample by country. Figure 1 depicts the co-movement with the euro area aggregates of the volume of lending and lending rates. A few observations are worth mentioning. First, the correlation with the euro area aggregates is relatively high, which indicates that our dataset is quite representative for the euro area banking sector. Specifically, the correlation between monthly growth rates of aggregate euro area lending to households and firms constructed

\footnotetext{
${ }^{9}$ The weights are calculated as a 12 -month average of the volumes of lending to households and firms to avoid creating artificial volatility in the series due to composition changes.
} 
using our dataset, and the official numbers published by the ECB is 0.73 , while the correlation between monthly changes in officially published euro area bank lending rates and those constructed based on the bank-level data is 0.88. Another interesting observation from the figures is the considerable dispersion between individual banks, which suggests that banks behaved very differently during the sample period and that the responses to common shocks have been very diverse.

\subsection{Credit support policy shocks}

A crucial issue for the analysis is the unconventional monetary policy indicator used for the estimations, i.e. the variable MPshock $k_{t}$ in equation (1). In this paper, we consider the effectiveness of the Eurosystem's credit support policy measures, which were aimed to provide ample liquidity to the banking sector in order to restore the monetary transmission mechanism and boost the supply of bank loans. ${ }^{10}$ Examples of such policies are several fine-tuning liquidity providing operations in the second half of 2007 , the shift from a variable rate tender to a fixed rate tender with full allotment in October 2008, various ameliorations to the collateral requirements, and the maturity extensions of the liquidityproviding operations. The Eurosystem has also conducted outright purchases of financial assets like covered bonds, asset-backed securities and government bonds to provide extra liquidity to the banking sector. In essence, all these measures have expanded the balance sheet of the Eurosystem for a given policy rate. The balance sheet of the Eurosystem can thus be considered as a reasonable indicator of the credit support policies. To properly estimate the consequences of the policies on bank lending, however, it is crucial to disentangle exogenous shifts in the central bank balance sheet from endogenous responses to fluctuations in the economy and financial markets. Failing to account for the fact that the policy measures and central bank balance sheet, just like loan demand and supply, react to the business cycle and financial gyrations, can bias the estimated effects considerably. In fact, this problem is often ignored in the literature investigating the effects of conventional monetary policy on bank lending, as many studies simply use the observed short term interest rate as an indicator of monetary policy. ${ }^{11}$

\footnotetext{
${ }^{10}$ Notice that the Eurosystem has conducted several types of non-standard monetary policy measures in response to the crisis, including communication policies and large-scale asset purchases. However, in this paper, we only investigate the effectiveness of liquidity support measures to stimulate bank lending.

${ }^{11}$ Papers examining the transmission of conventional monetary policy at the bank level that do consider exogenous policy shocks have used different approaches to do so. Bluedorn, Bowdler and Koch (2013), for instance, use an exogenous policy measure akin to the Romer and Romer (2004) methodology, and find much stronger dynamic effects and greater heterogeneity in lending across US banks compared to papers that consider plain interest rate movements, which can be prone to endogeneity. Others, e.g. Gambacorta
} 
As the monetary policy indicator, we therefore use the series of exogenous balance sheet shocks of Boeckx et al. (2017), who apply a structural VAR methodology to identify shocks to the Eurosystem's balance sheet that are orthogonal to real economy fluctuations, disturbances in financial markets, changes in the demand for central bank liquidity and conventional shifts in the monetary policy rate. Notice that there exist other studies that estimate the macro consequences on the euro area economy of unconventional monetary policies during the crisis period, but none of these studies identify shocks that (solely) capture the credit support policies. ${ }^{12}$

Boeckx et al. (2017) use a mixture of plausible zero and sign restrictions to identify exogenous policy induced innovations to the central bank balance sheet. Specifically, it is assumed that expansionary balance sheet shocks have no immediate impact on GDP and consumer prices, are orthogonal to changes in the MRO policy rate, and do not increase the CISS indicator and the EONIA-MRO spread on impact. Besides the balance sheet of the ECB, these are also the variables that are included in the VAR model (see section 2.1). The assumption that there is only a lagged impact on GDP and consumer prices allows to disentangle the shocks from real economy disturbances. Whereas this assumption may be questionable at the quarterly frequency (Canova and Pina 2005), it is plausible for monthly estimations. It can, for example, be justified by inertia characterizing agents' decisions about pricing and output levels because they are rationally inattentive (e.g. Sims and Zha 2006). The sign restriction on the CISS indicator disentangles the shocks from endogenous responses of the balance sheet to financial stress (Gambacorta et al. 2014), while the sign restriction on the EONIA-MRO spread allows to disentangle supply-driven changes in the ECB balance sheet from changes in the demand for central bank liquidity. For a more detailed discussion, we refer to Boeckx et al. (2017) or Burriel and Galesi (2018).

The time series of the shocks are shown in Figure 2, together with $68 \%$ credible set. The scale is measured in standard deviations of the shocks. A rise corresponds to expansionary balance sheet shocks, while a decline reflects a tightening relative to the average endogenous response of the balance sheet to the shocks hitting the economy. As can be observed, the shocks capture very well several important credit support measures of the Eurosystem, such as the one-year and three-year LTROs, the shift to a fixed-interest rate full allotment strategy, the Covered Bonds Purchase Programmes and the start of the

and Marqués-Ibáñez (2011), have used deviations from the Taylor rule as a proxy for conventional monetary policy shocks.

${ }^{12}$ For example, Altavilla et al. (2015) use high frequency data to assess how the announcements of the ECB's asset purchases programme have affected financial variables, while Jardet and Monks (2014) use high frequency intraday interest rate data to identify shocks to respectively the current and expected future path of the interest rate. 


\section{TLTROs.}

Figure 3 depicts the macroeconomic effects of the balance sheet innovations based on the VAR model. The full (blue) lines are the median impulse responses for a one-standard deviation shock, while the shaded (grey) areas represent the $68 \%$ credible sets of the estimated responses. An expansionary balance sheet innovation corresponds to a rise in central bank total assets by approximately 1.5\%. Overall, the balance sheet shocks have been successful in stimulating the economy. An open question is whether at least part of the stimulus came from a rise in credit supply of banks. This is what we assess in the next subsection.

\subsection{Empirical results}

The benchmark estimation results are reported in Figure 4. More specifically, the figures show the estimated values of $\theta_{h}$ for up to 24 months after the exogenous balance sheet shocks. ${ }^{13}$ The grey areas are $68 \%$ and $90 \%$ credible sets that are adjusted for possible correlations between the residuals of the banks at a moment in time (e.g. as a consequence of common shocks), as well as serial correlation between the residuals over time (e.g. when common shocks are persistent). These are calculated as discussed in Thompson (2011). Overall, the adjustments increase the standard errors relative to conventional robust standard errors. ${ }^{14}$ To account for the uncertainty associated with the estimation of the credit support policy shocks, we use the following procedure to estimate $\theta_{h}$ and the credible sets. First, for 500 draws from the posterior distribution of the shocks obtained from the VAR (step 1), we estimate the panel local projections (step 2). In the second step, for each draw of the first step, we generate 100 draws of the coefficients, assuming normality whilst taking into account the adjustment of the standard errors. The figures report the median of all 50,000 draws, together with 16-84 and 5-95 percentiles. As is typically the case for local projections, the patterns of the dynamic effects are quite erratic. In the appendix, we therefore also show the results when we use a smoothed local projections

\footnotetext{
${ }^{13}$ For the bank lending rates, we only show the responses for the first 12 months because the effects become positive at longer horizons. An explanation for this reversed pattern after a couple of months is the pass-through to lending rates of the (endogenous) tightening in the policy rate as the economy improves after a balance sheet expansion (which can be seen in Figure 3).

${ }^{14}$ Given that the credit support policy shocks are common and not correlated across time, also clustering by banks would not reduce a possible bias of the standard errors of the impulse responses, even if the residuals have significant bank components. On the other hand, clustering typically increases the variance of the standard errors, which implies that we could find statistical significance even when it does not exist. Accordingly, it is better not to cluster by banks for (common) regressors that are not correlated across time. See Thompson (2011) for a more detailed explanation.
} 
estimator as proposed in Plagborg-Moller (2016) and Barnichon and Brownlees (2019) as a robustness check. It turns out that this does not affect the conclusions.

The top row of Figure 4 shows the panel results for respectively the volume of lending and the lending rate. As can be observed, exogenous innovations to the Eurosystem's balance sheet did stimulate bank lending during the crisis period, both by increasing lending volumes and by reducing rates. Specifically, a credit support policy shock which expands the balance sheet of the Eurosystem by $1.5 \%$ leads to a decline in bank lending rates by roughly 3 basis points after one month, which lasts for about four months. On the other hand, there is a persistent (up to two years) rise in the volume of lending to households and firms, which reaches a peak of approximately 5 basis points. The opposite co-movement of the volume of lending and the lending rates denotes that the expansion of bank credit is essentially supply-driven. The (insignificant) rise of bank lending rates after six months can be explained by the response of the policy rate documented in Figure 3 , which, in turn, is a consequence of the improved macroeconomic conditions after an expansionary credit easing shock (or a decline of the policy rate in response to deteriorating macroeconomic conditions after a negative shock). The immediate reaction of lending rates, whose decline lasts only a few months, stresses the importance of using monthly data to estimate the consequences of the shock on bank lending rates. For example, studies that use data with a lower frequency, e.g. annual data, probably miss such effects.

Noticeably, the panel results turn out to be very similar to estimates obtained from euro area aggregate lending behavior, both in sign and magnitude. More precisely, the second row of Figure 4 shows the results of local projections applied to the aggregate volume of lending and lending rates, respectively. The similarity between the panel and aggregate results supports the representativeness of our sample of banks for the whole euro area. The magnitudes and patterns are also in line with the area-wide VAR estimates of Boeckx et al. (2017).

The third row of Figure 4 shows the results of a robustness check of the benchmark specification that includes the country-specific unemployment rate and the volume of debt security issuance by NFCs as additional control variables. The results turn out to be robust for this extension. Furthermore, the bottom row of Figure 4 shows the results when we use the Mean Group estimator. Specifically, whereas the baseline PMG estimator of Pesaran et al. (1999) allows all coefficients and error variances to differ across banks, the effects of credit support policy shocks on bank lending $\left(\theta_{h}\right)$ are assumed to be the same across banks. However, in the presence of heterogeneity, this assumption could bias the results. The MG estimator, in contrast, also allows the effects of the shocks to be 
heterogeneous across banks $\left(\theta_{i, h}\right)$. In fact, in section 3 , we will show that the effects are indeed heterogeneous depending on several bank characteristics. As can be observed in the figure, allowing for heterogeneity does not influence the estimation of the average effects, i.e. the rise in the volume of bank credit and decline in bank lending rates is nearly identical to the benchmark panel results. Finally, in the appendix we show that the findings are also robust when we use a smoothed local projections estimator. In sum, we can conclude that the Eurosystem credit support policies did stimulate bank lending to the private sector.

\section{Transmission mechanism of credit easing policies}

So far, we have shown that the non-standard monetary policy measures which have expanded the balance sheet of the Eurosystem in the aftermath of the financial crisis have been effective in stimulating bank lending to households and firms. In this section, we investigate the transmission mechanism in more detail. More precisely, in section 3.1, we extend the baseline empirical specification allowing for an influence of bank characteristics on the effectiveness. Section 3.2 discusses the potential channels and the indicators we use to proxy these channels, while section 3.3 reports the estimation results. Finally, in section 3.4 , we re-examine the role of bank capital taking into account possible nonlinearities.

\subsection{Empirical specification}

We examine the transmission mechanism by exploring whether there are significant differences in the way that banks with distinct characteristics respond to the Eurosystem's balance sheet shocks. To do this, we extend the baseline local projections of section 2 as follows: ${ }^{15}$

$$
\begin{aligned}
Z_{i, t+h}= & \alpha_{i, h}+\delta_{i, h}(L) Z_{i, t}+\rho_{i, h}(L) X_{t}+\sum_{j} \psi_{j, h} D U M_{j}+\sum_{k} \zeta_{k, h} \operatorname{char}(k)_{i, t-1} \\
& +\left(\gamma_{0, h}+\sum_{j} \gamma_{j, h} D U M_{j}+\sum_{k} \gamma_{k, h} \operatorname{char}(k)_{i, t-1}\right) M P \operatorname{shock} k_{t}+\varepsilon_{i, t+h}
\end{aligned}
$$

where $D U M_{j}$ are 19 country dummies, and $\operatorname{char}(k)_{i, t-1}$ a vector of $k$ individual bank characteristics. All other variables are the same as in the baseline specification. We include

\footnotetext{
${ }^{15}$ A similar approach is used in De Winne and Peersman (2019) to study the relationship between food prices and conflict using local projection methods.
} 
the country dummies to capture country-specific demand or other country-specific effects that may influence the impact of the policy measures on bank lending activities. Boeckx et al. (2017) find very diverse output consequences of the balance sheets shocks in individual euro area countries, in particular more subdued effects in the countries that have been more affected by the financial crisis. It is not clear whether this is the consequence of different national banking sectors (e.g. these countries typically have low-capitalized banks), or other country-specific features. For example, there may be less appetite (demand) for bank loans when households and firms are deleveraging their balance sheets, or countries may benefit differently from the exchange rate depreciation induced by the monetary expansion. Put differently, we explore the differences of bank characteristics within countries to assess the relevance for the effectiveness of credit support policies. To avoid endogeneity problems, we take the characteristics at $t-1$. Besides the interaction with the policy shock, the country dummies and bank characteristics are also included as additional control variables in equation (2) to avoid a possible omitted variables bias. The choice of the bank characteristics and motivation are discussed in the next subsection.

\subsection{Bank lending view of monetary transmission}

The bank characteristics that we consider in the empirical analysis can all be motivated by the so-called "bank lending view" of monetary transmission. The central idea of the lending view is the proposition that monetary policy actions can trigger an independent shift in the supply of bank loans (Bernanke and Blinder 1988). In essence, this view relies on the failure of the Modigliani-Miller proposition for banks, i.e. not all sources of funding are alike. In such an environment, a policy induced decrease in bank reserves (and hence in insured deposits, i.e. covered by deposit insurance) forces banks to shift to non-reservable uninsured deposits to finance their lending activities. Due to agency costs and adverse selection problems associated with depositors lending to banks, these alternative sources of funding are more expensive, which results in a contraction of banks' loan supply.

It is usually argued that the decline of loan supply is greater for constrained banks, while having little or no effect on the supply of loans of unconstrained banks, i.e. banks that can relatively easily obtain alternative (uninsured) external funds. Accordingly, the existence of the bank lending view is typically examined based on what the lending view has to say about the cross-sectional effects of monetary policy. Kashyap and Stein (1995), for example, argue that smaller banks are typically more exposed to asymmetric information problems, and have therefore more difficulties to substitute to non-deposit sources of 
funding. If the lending channel exists, a conventional monetary policy tightening, which is assumed to reduce bank reserves in this literature, should hence have a larger impact on the lending behavior of small banks. ${ }^{16}$ Similarly, several studies emphasize bank capital as an important constraint to obtain external funding, i.e. monetary policy is argued to have greater effects on loan supply of capital-constrained banks relative to banks with sufficient capital buffers (e.g. Kishan and Opiela 2000).

In this paper, we use a similar approach to examine the pass-through of the credit support policy measures implemented in the aftermath of the financial crisis. The starting point is not a policy-induced shift in insured bank deposits that forces banks to substitute towards more expensive forms of funding, but a situation where banking markets are severely impaired and banks have difficulties to obtain unsecured external sources of funds, unless they pay a significant risk premium. As argued by the proponents of the bank lending view, the borrowing constraints and external finance premium depend on the underlying balance sheet characteristics of banks. Those banks that are more constrained to obtain external funding should therefore also respond more to changes in credit support policies. For example, an enlargement of the pool of collateral accepted for refinancing operations should benefit constrained banks more than banks that have little difficulties to obtain unsecured sources of funding. Similarly, the launch of three-year LTROs should reduce the marginal cost of funding more for those banks that otherwise have to pay a relatively high external finance premium for non-secured long-term funding (e.g. bank bonds). Accordingly, constrained banks are expected to also increase the supply of credit to households and firms more than banks that are less constrained. Conversely, constrained banks likely curtail their lending activities more in the wake of restrictive balance sheet shocks. In contrast to the conventional bank lending view, in which monetary policy induces a shift in the volume of insured retail deposits, the transmission mechanism of the credit support policies to bank lending implies a shift in the availability and conditions (e.g. maturity, collateral, ...) of central bank liquidity to the banking sector. Put differently, the Eurosystem's credit easing measures allow banks to substitute market funding with central bank money, reducing the marginal cost for their lending activities. Below, we discuss a set of frictions at the level of financial intermediaries that should reflect the borrowing constraints and access to external sources of funding, and the corresponding bank characteristics that make banks' marginal cost of funding and lending behavior more or less sensitive to credit support policies.

\footnotetext{
${ }^{16}$ See Disyatat (2010) for a reformulation of the bank lending channel, emphasizing more how monetary policy affects banks' balance sheet strength and risk perception, which in turn affects their ability to obtain external funding, rather than focus on alterations to bank reserves.
} 
Size effect As we have discussed above, banks that are more constrained to raise uninsured external funding, are expected to respond more to credit support policies that increase the availability of central bank liquidity. In the bank lending view, the access to uninsured debt is typically proxied by bank size. In particular, this literature postulates that large banks have less difficulties to raise such funding because information costs are lower and there is more asset diversification compared to small banks. In addition, there might be an implicit "too big too fail" put option provided by the government. Building on this proposition, Kashyap and Stein $(1995 ; 2000)$ separate banks by asset size and find that small banks are more responsive to conventional monetary policy. If the lending view also applies to the credit support measures, one should expect the loan portfolio and lending rates of large banks to respond less to the balance sheet innovations of the Eurosystem. In the empirical analysis we include the natural logarithm of banks' total assets as one of the bank characteristics in equation (2), and label this channel as a size effect of the policies. The data for this measure is collected from the IBSI database, and hence available at a monthly frequency. For each bank we use the outstanding amount at the end of the month of total main assets.

Retail deposits effect A second bank characteristic that we include in the estimations is the ratio of retail deposits to total lending to households and firms. This series is also constructed based on the IBSI balance sheet items, and available at a monthly frequency. The reason we consider this variable is that a large share of retail deposits are covered by the deposit insurance schemes of the government, in contrast to market-based funding where credit risk matters. Banks with lower retail to total lending ratios are therefore more exposed to asymmetric information problems and are relatively more influenced by funding conditions in the market. Thus, a greater dependence on market-based sources of funds should be associated with more responsive loan supply schedules to shifts in the availability of liquidity, while banks that predominantly fund their lending activities with insured retail deposits should be more insulated from impaired financial markets and are probably less sensitive to credit support policies. ${ }^{17}$ Ivashina and Scharfstein (2010) show, for example, that banks which had better access to deposit funding and were less dependent on short-term debt, have reduced their lending activities less during the crisis. Also Dagher and Kazimov (2015) find that banks which are heavily reliant on wholesale

\footnotetext{
${ }^{17}$ A similar point has been made by Disyatat (2010) in the context of conventional monetary policy. Specifically, Disyatat (2010) argues that monetary policy affects bank lending mainly through variations in banks' external finance premium, rather than the availability of deposits, i.e. through prices rather than quantities.
} 
funding curtail their lending more than other banks during crises. Notice also that retail deposits have been much more stable than market-based funding during the financial crisis.

Liquidity effect Kashyap and Stein (2000) assert that less liquid banks should respond more to monetary policy actions in an environment where there are limitations in raising unsecured external debt because more liquid banks can relatively easily protect their loan portfolios by adjusting the stock of securities or by using them as collateral to obtain external funding. For the same reason, banks with sufficient liquidity buffers are likely less sensitive to changes in the volume of liquidity offered by the Eurosystem to the banking system. In contrast, less liquid banks can, for instance, not as easily make up for the funding shortfall of a restrictive balance sheet shock by raising external finance. These banks are essentially liquidity constrained for their lending activities, and are probably more sensitive to unconventional liquidity operations of the central bank. Accordingly, as a third balance sheet characteristic, we include the ratio of liquid assets over total assets in the estimations to proxy a possible liquidity effect of the credit support measures.

For the baseline estimations, we use the ratio of securities to total assets to measure banks' liquidity, which can also be constructed based on the IBSI balance sheet items at the monthly frequency. Securities include government securities issued by euro area governments and the private sector (not securities issued by non-EA countries). As a robustness check, we also use a series that we collected from the SNL Financial database, i.e. the ratio of cash and cash related equivalents such as securities held for trading to total assets. This alternative measure is probably a better proxy for liquidity, but is only available at the annual frequency, which implies that the bank characteristics at $t-1$ always reflect the situation in December of the previous year. Another caveat in the context of our analysis is that the SNL Financial liquidity ratio is not available for all banks over the entire sample period, i.e. there are a large number of missing observations.

Capital effect Finally, several studies have emphasized the role of bank capital as an important constraint for bank lending activities. Specifically, it is argued that contractionary monetary policy has severe adverse effects on the volume of loans of capital-constrained banks relative to unconstrained banks because banks with higher capitalization have easier access to uninsured and unsecured funds. The reason is that the amount of capital acts as a signaling mechanism to alleviate informational asymmetries between banks and their creditors, mitigating adverse selection and moral hazard problems in the market for unsecured bank liabilities. Put differently, from the perspective of banks' creditors, bank 
capital provides a buffer to absorb future losses, which, in turn, determines the extent of their willingness to lend to banks. Several empirical studies (e.g. Bernanke and Lown 1991; Kishan and Opiela 2000; Gambacorta and Mistrulli 2004; Albertazzi and Marchetti 2010; Jiménez et al. 2012, among others) find a positive relationship between capitalization and loan supply, with better capitalized banks reducing lending supply less than other banks in case of negative shocks, including contractionary monetary policy. Furthermore, Maechler and McDill (2006) find that banks in poorer conditions have to pay a risk premium on their uninsured deposits, while Gambacorta and Shin (2016) provide evidence that bank equity is an important determinant of the funding costs of banks.

To capture the role of bank capital for the transmission of the credit support policies, we use the (annual) equity to total assets ratio from SNL Financial, which is the ratio of total equity to total assets. We select this simple accounting measure of capital rather than a capital ratio based on risk-weighted assets, because this series is available for many more banks in our sample period. However, as a robustness check, we also show results when we use the Tier-1 capital ratios for fewer banks. ${ }^{18}$

Table 2 summarizes the characteristics of the banks that are included in the benchmark estimations. The average bank in our sample had a size of $€ 91$ bn over the period 20072015 , with substantial dispersion across banks. The distribution of total assets is quite skewed, with a median value of $€ 36 \mathrm{bn}$, indicating the presence of a large number of relatively small banks and a limited number of very large institutions. The skewness, however, vanishes for the (100 times) natural logarithm of total assets, which is the variable used in the estimations.

The share of liquid assets over total assets decreased somewhat over the same period. On average over the entire sample, liquid assets held by banks amounted to $10.7 \%$ of their total assets. While the median $(9.1 \%)$ is relatively close to the mean, there is a non-negligible right-side tail, indicating a sizable proportion of highly liquid banks. The average equity-to-assets ratio stood just below $6 \%$, with dispersion relatively limited. After the crisis and especially in recent years, particularly due to changes in regulation and supervision but also increased market scrutiny, banks increased their capital ratios, while dispersion in the degree of capitalization rose. Retail deposits amounted to $82 \%$ of retail lending in our sample on average, increasing notably over the sample period. Although the values are relatively low, some of the bank characteristics appear to be correlated:

\footnotetext{
${ }^{18}$ We have also estimated models with CET-1 capital ratios. Given the very strong correlation between Tier-1 and CET-1 (i.e. 0.98) and the fact that the results are nearly identical, in the paper we only show the results for Tier-1 as a robustness check. The results for CET-1 are available on request.
} 
better capitalized banks seem to be typically smaller, less liquid and more funded by retail deposits. Smaller banks are less liquid, while retail-funded banks are more liquid. Given the presence of these correlations, it is important to disentangle the effects of all the channels, and consider the characteristics simultaneously in the estimations. Our local projections framework allows to do so.

\subsection{Results}

Figure 5 shows the benchmark results for the impact of the bank characteristics on the effectiveness of credit support policies to stimulate bank lending, i.e. the estimated values of $\gamma_{k, h}$ for each bank characteristic $k$ at horizon $h$ after the Eurosystem's balance sheet shocks (see equation 2). All bank characteristics are demeaned and normalized by their standard deviation prior to the estimations, and can thus be interpreted as the additional impact of the balance sheet shock on respectively the volume of lending and lending rates when the bank characteristic deviates by one standard deviation from its sample mean. Notice that the average effects are essentially the impulse responses reported in Figure 4 and discussed in section $2 .{ }^{19}$

The results reveal that the volume of lending of large (small) banks responds less (more) to credit easing shocks, which confirms the existence of a size effect: a bank that is one standard deviation smaller relative to the sample mean increases its volume of lending up to 5 basis points more one year after the policy shock. Compared to the average effects that we have obtained, i.e. a peak effect of 5 basis points, the influence of the size effect is economically very important for the transmission of credit support policies. Also the retail funding effect has the expected negative sign, although only at longer horizons. Specifically, banks that are less dependent on the wholesale market and mainly fund their lending activities with retail funding turn out to be less responsive to credit easing policy shocks after one year. A one-standard-deviation rise in the retail funding to total lending ratio reduces the response of bank lending between 2 and 3 basis points. Again, compared to the average effects, the magnitude is economically relevant.

On the other hand, we find mixed results for the impact of capital and liquidity ratios on loan provision. The influence of liquidity appears to be positive the first year after the shocks, in order to become negative in the second year. For bank capital, we find a significant positive effect after one year. Both results are surprising and at odds with the

\footnotetext{
${ }^{19}$ There could be a slight deviation since the country-specific dummies and bank characteristics are also directly included as additional control variables to avoid a possible omitted variables bias.
} 
bank lending view. In particular, better capitalized and more liquid banks are expected to be less dependent on central bank liquidity for their lending activities, and hence also less sensitive to the credit support measures of the Eurosystem. Although the results for capital are consistent with other studies, e.g. Boeckx et al. (2017) and Altavilla et al. (2016), this finding remains puzzling. It will be analyzed in more detail in section 3.4.

The bottom row of Figure 5 shows the results for bank lending rates. In principle, we expect the opposite sign of the coefficients for the volume of lending, but notice that banks can also increase credit supply without lowering their lending rates. For example, they could engage in riskier lending activities at the same lending rate. ${ }^{20}$ Such behavior and effects of credit easing policies are only observable in the volumes of lending, and not in the lending rates. This caveat and limitation of our dataset should be taken into account when interpreting the results. Nevertheless, the results for the lending rates are broadly in line with those based on the volume of lending. In particular, we find that the lending rates charged to households and firms of larger banks, and banks that are less dependent on the wholesale market, are significantly less responsive to credit policy shocks. Whereas banks lower lending rates on average by 3 basis points, this is roughly 1.5 basis points less for large banks, as well as banks with a high share of retail deposits. In addition, we find that highly capitalized banks lower their rates much more strongly than other banks, which is again surprising, while differences in the liquidity ratio do not seem to have any impact on bank lending rates. ${ }^{21}$

Figure 6 and 7 summarize several robustness checks for the influence of bank characteristics on the volume of lending and bank lending rates, respectively. The first column in both figures show the results for a specification that also includes the unemployment rate and the volume of debt security issuance by firms as additional control variables. It appears that the results are not sensitive to this extension.

In the second column, we control for the banks' business model. More specifically, we control (using dummy variables) for the fact whether the bank business model is Universal, G-SIB, Retail Lender, Corporate Wholesale or Specialized Lender. Qualitatively, the results are similar to the benchmark results. However, for the volume of lending, the

\footnotetext{
${ }^{20}$ Literature on the financial accelerator and the search for yield coincides on identifying mechanisms by which expansionary monetary policy may induce banks into engaging in higher risk taking (see Borio and Zhu, 2012). Empirical analyses seem to support this conclusion (Maddaloni and Peydrò, 2010; Ioannidou et al., 2009). Dell'Ariccia et al. (2011) propose a theoretical framework where banks' capital structure would influence the risk-taking of banks after a monetary policy shock.

${ }^{21}$ Due to the sign switch of the average effects after approximately 4-6 months, which can be explained by the endogenous response of the policy rate (see Figure 4 and section 2), only the effects during the first 4-6 months after the shock are relevant to evaluate the presence of the different channels.
} 
magnitude of the size effect and particularly the retail funding effect turns out to be much stronger. As can be seen in Figure 7, for the retail funding effect, this also applies to the impact on bank lending rates. Put differently, both effects become stronger once we control for the business model of the banks.

As a third robustness check, we replace the ratio of total equity to total assets by the Tier-1 capital ratio to proxy the bank capital effect. Again, the results are very similar. Notably, we do find the expected negative sign for the volume of lending, i.e. better capitalized banks seem to respond less to the credit support policies. For the lending rates, however, we still find the opposite of the expected sign. Finally, the last column shows the results when we use the alternative liquidity measure. For the volume of lending, the results are similar. On the other hand, for the influence on bank lending rates, the capital effect becomes more moderate and the retail funding effect even statistically insignificant. However, a more detailed analysis suggests that the reason for this is the lower number of observations, rather than the alternative liquidity indicator (roughly one-fourth of the observations are missing). Specifically, we obtain similar results for capital and retail funding effects when we estimate the benchmark specification for the reduced sample of banks.

\subsection{The role of bank capital}

The results in section 3.3 have revealed that loan supply of better capitalized banks tend to react more to the credit support policies of the Eurosystem. In fact, also Boeckx et al. (2017) document a strong positive correlation between the effects of central bank balance sheet innovations on economic activity in individual euro area countries and the Tier 1 capital ratio of the consolidated national banking system. Furthermore, Altavilla et al. (2016) find a stronger pass-through of unconventional monetary policy on lending rates of high-capitalized banks. These findings are striking in the light of the existing evidence on monetary policy and bank capital in normal times. In particular, given the role of capital as a sign of bank balance sheet strength and access to non-secured market funding, several studies find that low-capitalized banks typically respond more to changes in the policy rate, whereas higher bank capital ratios mitigate the effects on lending during periods of contractionary monetary policy.

Why do low-capitalized banks respond less to policy measures that raise their access to liquidity? A possible explanation is that bank capital also encompasses a drag on the ability to increase loan supply. More precisely, a bank can extend loans up to a certain 
multiple of its capital, which is determined by regulatory capital requirements (first and foremost the Basle Agreements) or by market discipline. When banks are close to the regulatory minimum, they cannot expand lending without additional capital, which was very difficult and costly to raise during the sample period. Van den Heuvel (2007) shows that it is not even necessary for the capital constraint to bind today in order to influence bank lending behavior. In other words, to avoid a binding constraint in the future, banks might already act as if the constraint is binding today. An expected higher risk embedded in lending over the period of the sample (due to adverse economic conditions) could amplify the problem, as their capital buffer could need to be larger in order to be able to absorb more substantial expected losses.

The role of bank capital for lending activities through regulatory requirements rather than serving as a buffer for potential losses of uninsured depositors has also been postulated in the literature on conventional monetary policy. For example, Bernanke and Lown (1991) argue that the bank lending channel will be shut down, and the real effects of a given monetary policy expansion will be smaller when bank capital hits the regulatory minimum for a sizeable fraction of banks. Albertazzi and Marchetti (2010) provide empirical evidence supporting such a "capital crunch".

If capital serves as a fundamental constraint on credit supply of banks, it may hence also limit the effectiveness of the credit support policies, in particular the size, liquidity and retail deposits effects. To investigate whether this is the case, we estimate two extensions of equation (2). First, we extend the baseline bank characteristics with a simple dummy variable, which is equal to one for banks that have a capital ratio which is in the lowest quartile (Q4) of the whole sample. These banks should have most difficulties to increase credit supply. Second, we extend the set of bank characteristics in equation (2) by allowing for interaction of bank capital with the other characteristics. Specifically, we also include size*capital, liquidity*capital and retail*capital as explanatory variables in the vector of bank characteristics (and vector of control variables to avoid a possible omitted variables bias). If capital indeed imposes a constraint on the effectiveness of the other channels, the estimated coefficients should be positive (negative) for the coefficients in the volumes (rates) equations.

The results for the estimations with the dummy variable are shown in Figure 8. While the size, retail funding and liquidity effects are similar to the benchmark results, the role of capital is clearly different when we account for capital constraints. In particular, as can be observed in the figures, (very) low-capitalized banks seem to have responded considerably less to the policies than the other banks, with persistently lower (up to 10 basis points) 
lending volumes and higher (roughly 3 basis points) lending rates. Thus, it appears that low capital ratios have indeed encompassed a drag on the ability of several banks to increase loan supply in response to the credit support measures. The magnitudes are economically very important and statistically significant. Interestingly, when we control for these lowcapitalized banks, and in contrast to the benchmark results, also the coefficients for capital have the expected sign for the volume of lending. Specifically, better capitalized banks, which typically have easier access to unsecured external funding, responded significantly less to the credit support policies. ${ }^{22}$ Also for bank lending rates, the counterintuitive negative coefficient for the capital effect documented in Figure 5 vanishes and becomes insignificant, even though there is no sign switch. As can be observed in Figure 9-10, the finding of a significant negative impact of the low capital dummy on the effectiveness of credit support policies during the sample period, as well as the expected sign of the capital effect for the volume of lending, seems to be robust for several alternative estimations of the local projections models. The same applies to the smoothed impulse responses shown in the appendix.

Figure 11 shows the estimation results for the specification with the interactions of bank capital with the other characteristics. The coefficients and their interaction with capital, for example "size" and "size*capital", should be interpreted as follows: if the size (total assets) of a bank deviates by one standard deviation from the sample mean, the coefficient of "size" measures the additional effect of credit support policies on the banks' lending volume (rates), when the capital ratio of the bank is equal to the sample mean. The coefficient of "size* capital", in turn, represents the additional effect of size on the volume of lending and lending rates (i.e. on top of the above size effect) if, at the same time, also capital deviates by one standard deviation from the sample mean. ${ }^{23}$

The impact of size, retail funding, liquidity and capital on the volume of lending now all have the expected sign as postulated in the bank lending view. All coefficients are significantly negative at several horizons, indicating that banks that have more difficulties to raise uninsured or unsecured external funding react more to the credit support measures of the Eurosystem. The magnitudes of the effects are also larger than in the specification

\footnotetext{
${ }^{22}$ For banks in the lowest quartile, the negative dummy effect dominates the positive "direct" capital effect so that the overall response to credit support shocks is weaker.

${ }^{23}$ Notice that, if $\mu_{\text {size }}$ and $\mu_{\text {capital }}$ are the sample means of size and capital, respectively, $\gamma_{1}\left(\right.$ size $\left.-\mu_{\text {size }}\right)+\gamma_{2}\left(\right.$ capital $\left.-\mu_{\text {capital }}\right)+\gamma_{3}\left(\right.$ size $\left.-\mu_{\text {size }}\right)\left(\right.$ capital $\left.-\mu_{\text {capital }}\right)$ can be rewritten as $\left[\gamma_{1}+\gamma_{3}\left(\right.\right.$ capital $\left.\left.-\mu_{\text {capital }}\right)\right]\left(\right.$ size $\left.-\mu_{\text {size }}\right)+\gamma_{2}\left(\right.$ capital $\left.-\mu_{\text {capital }}\right)$. Accordingly, $\gamma_{1}$ reflects the impact when capital is equal to the sample mean and size deviates one standard deviation from the sample mean, while $\gamma_{2}$ measures the additional effect of size when also capital is one standard deviation higher/lower than the sample mean.
} 
without interaction effects, and especially the direct effects of size and capital are large. Furthermore, also the coefficients of the interaction terms are all significant, and have the expected sign (although retail*capital only for a few quarters). This finding confirms that the degree of capitalization of banks is a constraint for the strength of the other effects, i.e. poorly capitalized banks are much less able to increase their lending activities when the Eurosystem increases the volume of liquidity available to the banking system. The capital drag is economically important. For example, banks that are one standard deviation smaller than the sample mean, increase the volume of lending by 10 basis points more than average after an expansionary credit policy shock, if all other bank characteristics are equal to their sample mean. However, if at the same time the capital ratio is also one standard deviation below average, the impact of size on the volume of lending is roughly 5 basis points less. Put differently, the size effect is only half as strong for relatively lowcapitalized banks. Similarly, the retail funding and liquidity effects are only half as strong when the capital ratio of a bank is one standard deviation below the sample mean. As shown in Figure 12, these findings are robust for size, retail funding and their interactions with capital. For the liquidity effect, however, the results turn out not to be robust when we use banks' Tier-1 capital ratios instead of the benchmark capital ratios.

The results are broadly confirmed for the effects of credit support policy shocks on bank lending rates, as shown in Figure 11 (bottom panel) and Figure 13, although less significant. Again, we find evidence in favor of size, retail funding and capital effects, while the latter two channels are more subdued for banks with relatively low capital ratios. For liquidity, we do not find a significant influence on bank lending rates. Overall, in contrast to the size, retail funding and capital effects, we are less confident about the existence of the liquidity effects. On the whole, based on the analysis in this section, we can conclude that banks having more difficulties to obtain unsecured external funding respond more to credit easing compared to other banks, but that the responsiveness vanishes when the banks have relatively low capital ratios. ${ }^{24}$

\section{Conclusions}

In response to the financial crisis, the Eurosystem has introduced a number of new policy tools that have expanded the size of the central bank balance sheet. The purpose of

\footnotetext{
${ }^{24}$ Notice that in principle one could also interpret the results as a bank capital effect of the policies, which mitigates when banks are larger, depend less on unsecured funding for their lending activities and have higher levels of liquidity. Although we cannot exclude this, such a mechanism is hard to motivate theoretically, in particular for the period under consideration.
} 
these tools was to support the functioning of financial markets and to provide additional stimulus to the economy when the policy rate was constrained near zero. Whereas the literature on the macroeconomic consequences of changes in the policy rate is vast, little is known about the effects of these alternative policy measures to stimulate the flow of credit to the private sector. Even less is known about the transmission mechanism. This paper is an attempt to fill this gap. To do this, we have estimated the effects of credit support policies on lending behavior for a panel of 131 euro area banks using Jordà's (2005) local projection methods.

In a first step, we show that such policy measures have been effective in stimulating bank lending to households and firms since the start of the financial crisis. Specifically, an expansion in the Eurosystem's balance sheet resulted in a fall of bank lending rates, and a rise in the volume of lending. In a second step, we investigate the role of different bank characteristics in explaining the pass-through to credit supply. Consistent with the bank lending view, we find that banks that were more constrained to obtain unsecured external funding during the crisis, responded also more to the policy measures. Liquidity policies by the central bank may thus alleviate funding constraints for banks. This is, however, much less the case for banks that have very low levels of capitalization. More precisely, we find that lending activities of banks that were smaller, haf less liquid assets, funded themselves less by retail deposits and were less well capitalized responded more to credit support measures. However, these effects are mitigated when a bank's capital position was weaker. As has been argued by Bernanke and Lown (1991) and Van den Heuvel (2007) for conventional monetary policy, a minimum level of capitalization (imposed by regulation or the market) appears to be a crucial condition for the other channels to be operative, as if capital acts like the ultimate constraint.

The implications of these findings are twofold. First, credit support measures, and the role of the central bank as lender of last resort, are effective to prevent a liquidity-driven credit crunch, but banks need to have a sufficient buffer over their minimum capital requirements to be able to transmit the easier financial conditions to the rest of the economy. From this perspective, the recent efforts to recapitalize euro area banks should enhance the effectiveness of such policies. Second, this also pleads in favor of countercyclical regulation, including sufficiently high countercyclical capital buffers, in order to avoid that binding capital requirements contribute to an even more severe reduction in credit. 


\section{A Appendix}

As explained in section 2.1, local projections are less efficient than e.g. structural VARs, which may lead to highly variable estimates of the impulse response functions due to, for example, sampling noise and outliers. In many applications, there are a priori reasons to believe that the true effects are smooth, but this requires strong assumptions. For example, Plagborg-Moller (2016) and Barnichon and Brownlees (2019) propose to use shrinkage estimators that impose smoothness of the impulse responses. To evaluate whether smoothing affect our conclusions, we re-estimate the main results of the paper by imposing smoothness on the dynamic effects. We follow Plagborg-Moller (2016) to do this. More specifically, given an initial non-smooth IRF estimator $\widehat{\beta}=\left(\widehat{\beta}_{0}, \ldots, \widehat{\beta}_{n-1}\right)^{\prime}$ and a scalar smoothing parameter $\lambda \geqslant 0$, Plagborg-Moller (2016) proposes to use the following smoothed estimator:

$$
\widehat{\beta}(\lambda)=\underset{\beta \in \mathbb{R}^{n}}{\arg \min } \sum_{i=0}^{n-1}\left(\beta_{i}-\widehat{\beta}_{i}\right)^{2}+\lambda \sum_{i=2}^{n-1}\left\{\left(\beta_{i}-\beta_{i-1}\right)-\left(\beta_{i-1}-\beta_{i-2}\right)\right\}^{2}
$$

A key parameter is $\lambda$, which represents the imposed degree to which the initial impulse response estimate is smoothed out. If $\lambda=0$, the smoothed estimator equals the nonsmooth initial estimate, while the estimator converges to a straight line if $\lambda \rightarrow \infty$. For $0<\lambda<\infty$, the smoothed estimator shrinks the initial estimate towards a straight line. ${ }^{25}$ A caveat is that $\lambda$ has to be chosen by the researcher prior to the estimations, which is rather arbitrary. Plagborg-Moller (2016) and Barnichon and Brownlees (2019) propose to choose the degree of smoothing by minimizing the mean squared error of the smoothed IRF estimator. However, for our application this is not possible since we have no point estimate, but a distribution of impulse responses (see section 2.1). In the figures, we therefore show the results for $\lambda=0$ (no smoothing), 1, 10 and 100. Notice also that, for technical reasons, we have used a bootstrap procedure to construct the credible sets (and the impulse responses), of which the theoretical properties have not been shown yet. ${ }^{26}$ The results should hence be interpreted with more than the usual degree of caution and only be considered as a robustness check of the benchmark results. Notwithstanding these caveats, as can be observed in the figures, the impulse responses and credible sets are very

\footnotetext{
${ }^{25}$ Notice that the smoothed estimator $\widehat{\beta}(\lambda)$ is essentially a Hodrick-Prescott trend of the artificial time series $\left(\widehat{\beta}_{0}, \ldots, \widehat{\beta}_{n-1}\right)$, which is easy to compute with standard software.

${ }^{26}$ In fact, the theoretical proporties of the confidence bands have also not been studied for all existing smoothed IRF estimators. A technical problem we encountered is that the sandwich estimator to cluster the standard errors collapses to zero (i.e. is not positive definite) for many draws of the VAR.
} 
similar to the benchmark results for $\lambda=0$ (no smoothing). The credible sets are even somewhat more conservative at longer horizons.

The smoothed impulse responses of all baseline results are shown in Figure A1-A7. The responses indeed become (much) smoother. For the volume of lending, the impulse responses appear more conventional for higher values of $\lambda$. In particular, for $\lambda=100$, the shape and magnitude of the volume of lending (Figure A1) is nearly identical to the VAR-based euro area aggregate impulse responses shown in Boeckx et al. (2017). For bank lending rates, however, the dynamic effects resemble more natural for low values of $\lambda$. This is not surprising since the decline in lending rates is relatively short-lived, and switches sign after approximately four months (also in the VAR-model of Boeckx et al. 2017), which is a pattern that corresponds to a very low degree of smoothness. Overall, the figures reveal that the magnitudes of the peak effects of the smoothed impulse responses are slightly more subdued than the unsmoothed effects, which is again not surprising. Nevertheless, all conclusions about the effectiveness of credit support policies discussed in the paper still hold and, thus, can be considered as robust for smoothing.

\section{References}

[1] Albertazzi, U and DJ Marchetti (2010), "Credit supply, flight to quality and evergreening: an analysis of bank-firm relationships after Lehman", Working Paper $\mathrm{n}^{\circ}$ 756, Bank of Italy.

[2] Altavilla, C., G. Carboni and R. Motto (2015), "Asset purchase programmes and financial markets: lessons from the euro area", ECB Working Paper 1864, November.

[3] Altavilla, C., F. Canova and M. Ciccarelli (2016), "Mending the broken link: Heterogeneous bank lending and monetary policy pass-through", ECB Working Paper, forthcoming.

[4] Andrade, P., C. Cahn, H. Fraisse and J-S. Mésonnier (2015), "Can the Provision of Long-Term Liquidity Help to Avoid a Credit Crunch? Evidence from the Eurosystem's LTROs," Working papers 540, Banque de France.

[5] Barnichon, R. and C. Brownlees (2019), "Impulse Response Estimation By Smooth Local Projections", The Review of Economics and Statistics, forthcoming.

[6] Bernanke, B. and A. Blinder (1988), "Credit, money and aggregate demand", American Economic Review, 78(2), 435-439. 
[7] Bernanke, B. S. and C. S. Lown (1991), "The Credit Crunch," Brookings Papers on Economic Activity, vol. 22, issue 2, pages 205-248.

[8] Bluedorn, J., Ch. Bowdler and Ch. Koch, (2013), "Heterogeneous Bank Lending Responses to Monetary Policy; New Evidence from a Real-time Identification," IMF Working Papers 13/118, International Monetary Fund.

[9] Boeckx, J., Dossche, M. and G. Peersman (2017), "Effectiveness and Transmission of the ECB's Balance Sheet Policies", International Journal of Central Banking, 13(1), 297-333.

[10] Borio, C. and H. Zhu (2012), "Capital regulation, risk-taking and monetary policy: A missing link in the transmission mechanism?," Journal of Financial Stability, vol. 8(4), 236-251.

[11] Burriel P. and A. Galesi (2018), "Uncovering the Heterogeneous Effects of ECB Unconventional Monetary Policies across Euro Area countries", European Economic Review, 101(C), 210-229.

[12] Canova, F. and J. Pina (2005), "What VAR Tell Us About DSGE Models?" , in Diebold and Kyrtsou (eds), New Trends In Macroeconomics, Springer Verlag.

[13] Colangelo, A. and M. Lenza (2013), "Cross-border banking transactions in the euro area," IFC Bulletins chapters, in: Bank for International Settlements (ed.), Proceedings of the Sixth IFC Conference on "Statistical issues and activities in a changing environment", Basel, 28-29 August 2012., volume 36, pages 518-531.

[14] Dagher, J. and K. and Kazimov (2015), "Banks' liability structure and mortgage lending during the financial crisis", Journal of Financial Economics, Volume 116, Issue 3 (June), 565-582.

[15] de Haan, L., Ph. Vermeulen and J.W. van den End (2016), "Lenders on the storm of wholesale funding shocks: saved by the central bank?", ECB Working Paper 1884, February.

[16] Dell'Ariccia, G., L. Laeven and R. Marquez (2011), "Monetary policy, leverage and bank risk-taking," CEPR Discussion Paper No. 8199.

[17] De Winne, J. and G. Peersman (2019), "The Impact of Food Prices on Conflict Revisited", Journal of Business and Economic Statistics, forthcoming. 
[18] Disyatat, P. (2010), "The bank lending channel revisited," BIS Working Paper No 297, February.

[19] Draghi, M. (2015), "The ECB's recent Monetary Policy Measures: Effectiveness and Challenges", Camdessus lecture at the IMF, Washington, DC, 14 May 2015

[20] ECB (2012), Manual on MFI Balance Sheet Staistics, April.

[21] Gambacorta, L., Hofmann, B. and G. Peersman (2014), "The Effectiveness of Unconventional Monetary Policy at the Zero Lower Bound: A Cross-Country Analysis", Journal of Money, Credit and Banking, 46(4), 615-42.

[22] Gambacorta, L. and D. Marqués-Ibáñez, (2011), "The bank lending channel: lessons from the crisis," Working Paper Series 1335, European Central Bank.

[23] Gambacorta, L. and P.E. Mistrulli (2004). 'Does bank capital affect lending behavior?', Journal of Financial Intermediation, 13(4), 436-57.

[24] Gambacorta, L. and H.S. Shin (2016), "Why bank capital matters for monetary policy", BIS Working Paper No 558, April.

[25] Ioannidou, V., S. Ongena and J. L. Peydró (2014), "Monetary Policy, Risk-Taking and Pricing: Evidence from a Quasi-Natural Experiment," European Banking Center Discussion Paper No. 2009-04S.

[26] Ivashina, V. and D. Scharsftein (2010), "Bank lending during the financial crisis of 2008", Journal of Financial Economics 97, 319-338.

[27] Jardet, C. and A. Monks (2014), "Euro Area Monetary Policy Shocks: Impact on Financial Asset Prices During the Crisis?", Banque de France Working Paper No. 512 , October

[28] Jiménez, G., S. Ongena, JL Peydró, J. Saurina (2012), “"Macroprudential policy, countercyclical bank capital buffers and credit supply: Evidence from the Spanish dynamic provisioning experiments," Working Paper Research 231, National Bank of Belgium.

[29] Jordà, Ó., "Estimation and Inference of Impulse Responses by Local Projections", American Economic Review vol. 95, no. 1, March (pp. 161-182).

[30] Kashyap A. and J. Stein (1995), "The impact of monetary policy on bank balance sheets", Carnegie-Rochester Conference Series on Public Policy, 42(1), 151-195. 
[31] Kashyap A. and J. Stein (2000), "What do a million observations say about the transmission of monetary policy", American Economic Review, vol. 90, no. 3, June 2000 (pp. 407-428).

[32] Kilian, L. and Y. Kim (2011), "How reliable are local projection estimators of impulse responses?", Review of Economics and Statistics, 93: 1460-1466.

[33] Kishan, R. P. and T. Opiela (2000), "Bank Size, Bank Capital, and the Bank Lending Channel," Journal of Money Credit and Banking 32(1):121-41, February.

[34] Kishan, R. P. and T. Opiela (2006), "Bank capital and loan asymmetry in the transmission of monetary policy," Journal of Banking and Finance 30, 259-285.

[35] Maddaloni, A. and J. L. Peydró (2010), ""Bank risk-taking, securitization, supervision and low interest rates: Evidence from the euro area and the U.S. lending standards," Working Paper Series 1248, European Central Bank.

[36] Maechler, A. and K. McDill (2006), "Dynamic depositor discipline in U.S. banks", Journal of Banking and Finance 30(7):1871-1898.

[37] Pesaran,M., Shin Y and R. Smith (1999), "Pooled Mean Group Estimation of Dynamic Heterogeneous Panels", Journal of the American Statistical Association, Vol. $94,621-634$.

[38] Plagborg-Moller, M. (2016), "Essays in Macroeconometrics", PhD dissertation, Harvard University.

[39] Romer, C. and D. Romer (2004), "A New Measure of Monetary Shocks: Derivation and Implications", American Economic Review, vol. 94, no. 4, September (pp. 10551084).

[40] Sims, C. and T. Zha (2006), "Were There Regime Switches in U.S. Monetary Policy?", American Economic Review, 96(1), 54-81.

[41] Thompson, S. (2011), "Simple formulas for standard errors that cluster by both firm and time", Journal of Financial Economics, 99, 1-10.

[42] Trichet, J.C. (2009), "The ECB's enhanced credit support", keynote address at the University of Munich, 13 July 2009.

[43] Van den Heuvel, S. (2007), "The bank capital channel of monetary policy," University of Pennsylvania Working Paper. 
Table 1 - Sample representativeness (October 2015)

\begin{tabular}{lccc}
\hline \hline Country & Number of banks & $\begin{array}{c}\text { Share of total } \\
\text { assets (\%) }\end{array}$ & $\begin{array}{c}\text { Share of retail } \\
\text { lending (\%) }\end{array}$ \\
\hline Austria & 6 & 28 & 30 \\
\hline Belgium & 6 & 40 & 64 \\
\hline Cyprus & 2 & 41 & 56 \\
\hline Germany & 41 & 37 & 36 \\
\hline Estonia & 2 & 62 & 64 \\
\hline Spain & 14 & 69 & 78 \\
\hline Finland & 1 & 7 & 7 \\
\hline France & 12 & 28 & 26 \\
\hline Greece & 1 & 21 & 21 \\
\hline Ireland & 2 & 10 & 28 \\
\hline Italy & 14 & 33 & 40 \\
\hline Lithuania & 1 & 27 & 32 \\
\hline Luxembourg & 5 & 12 & 41 \\
\hline Latvia & 2 & 28 & 42 \\
\hline Malta & 4 & 38 & 86 \\
\hline Netherlands & 6 & 60 & 68 \\
\hline Portugal & 5 & 63 & 70 \\
\hline Slovenia & 4 & 48 & 58 \\
\hline Slovakia & 31 & 37 & 43 \\
\hline Total euro area & & & 28 \\
\hline \hline
\end{tabular}


Table 2 - Bank characteristics

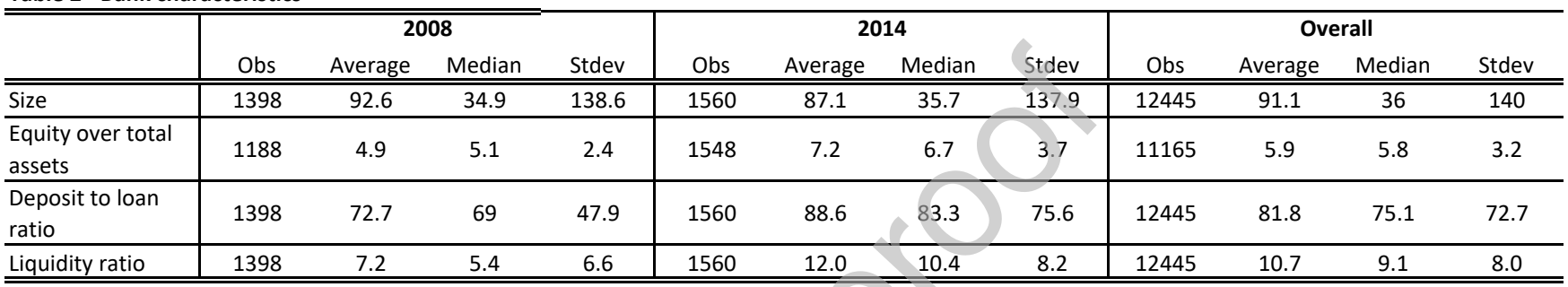

\begin{tabular}{|c|c|c|c|}
\hline Correlations & Size & $\begin{array}{l}\text { Equity } \\
\text { over total } \\
\text { assets }\end{array}$ & $\begin{array}{l}\text { Deposit to } \\
\text { loan ratio }\end{array}$ \\
\hline Size & 1.00 & & \\
\hline $\begin{array}{l}\text { Equity over total } \\
\text { assets }\end{array}$ & -0.19 & 1.00 & \\
\hline $\begin{array}{l}\text { Deposit to loan } \\
\text { ratio }\end{array}$ & -0.03 & 0.34 & 1.00 \\
\hline Liquidity ratio & 0.10 & -0.14 & 0.28 \\
\hline
\end{tabular}




\section{Journal Pre-proof}

Figure 1 - Time series of annual growth rate of bank lending and bank lending rate in the euro area and sample of individual banks
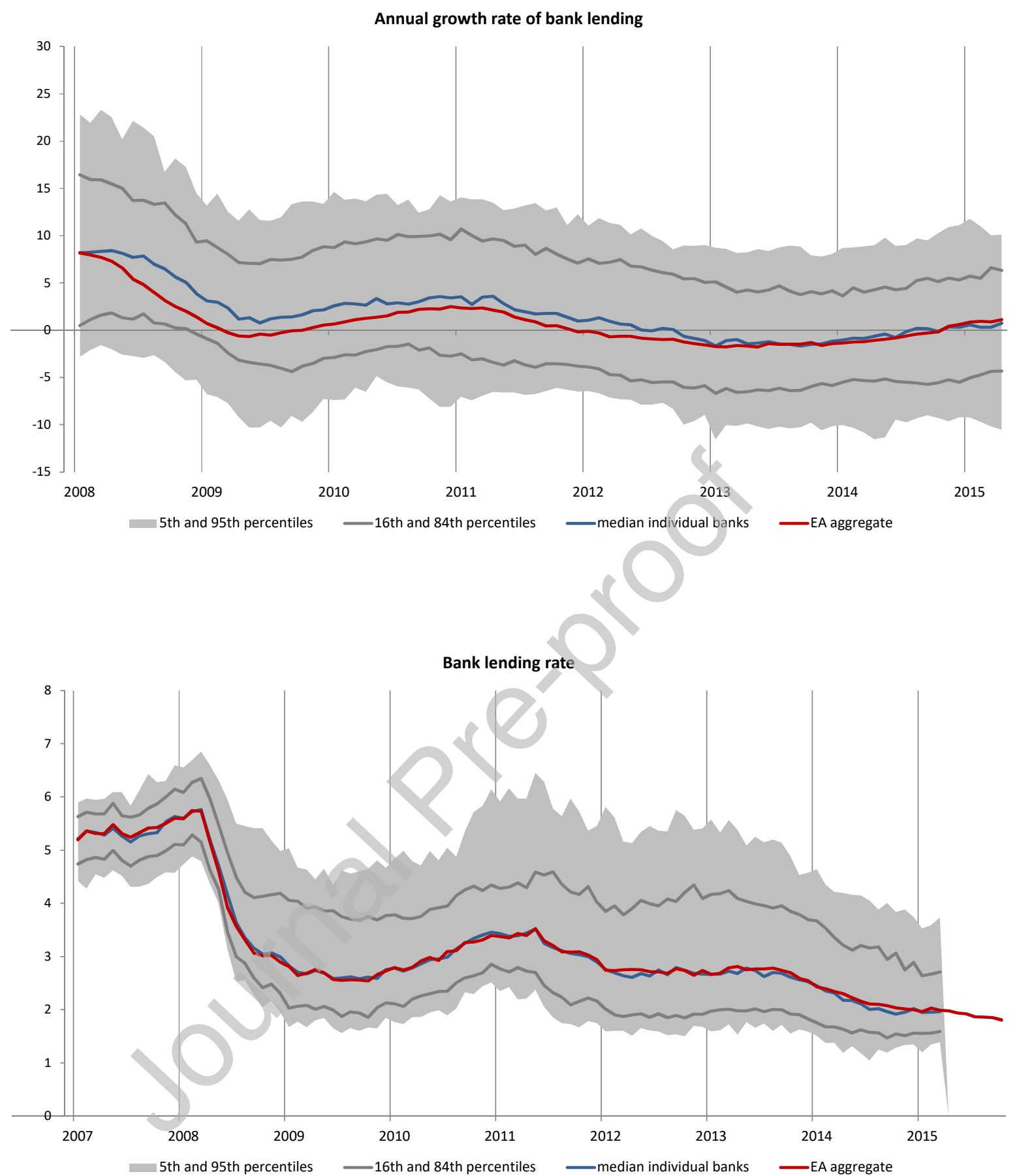
Figure 2 - Time series of balance sheet shocks (Boeckx et al. 2017)

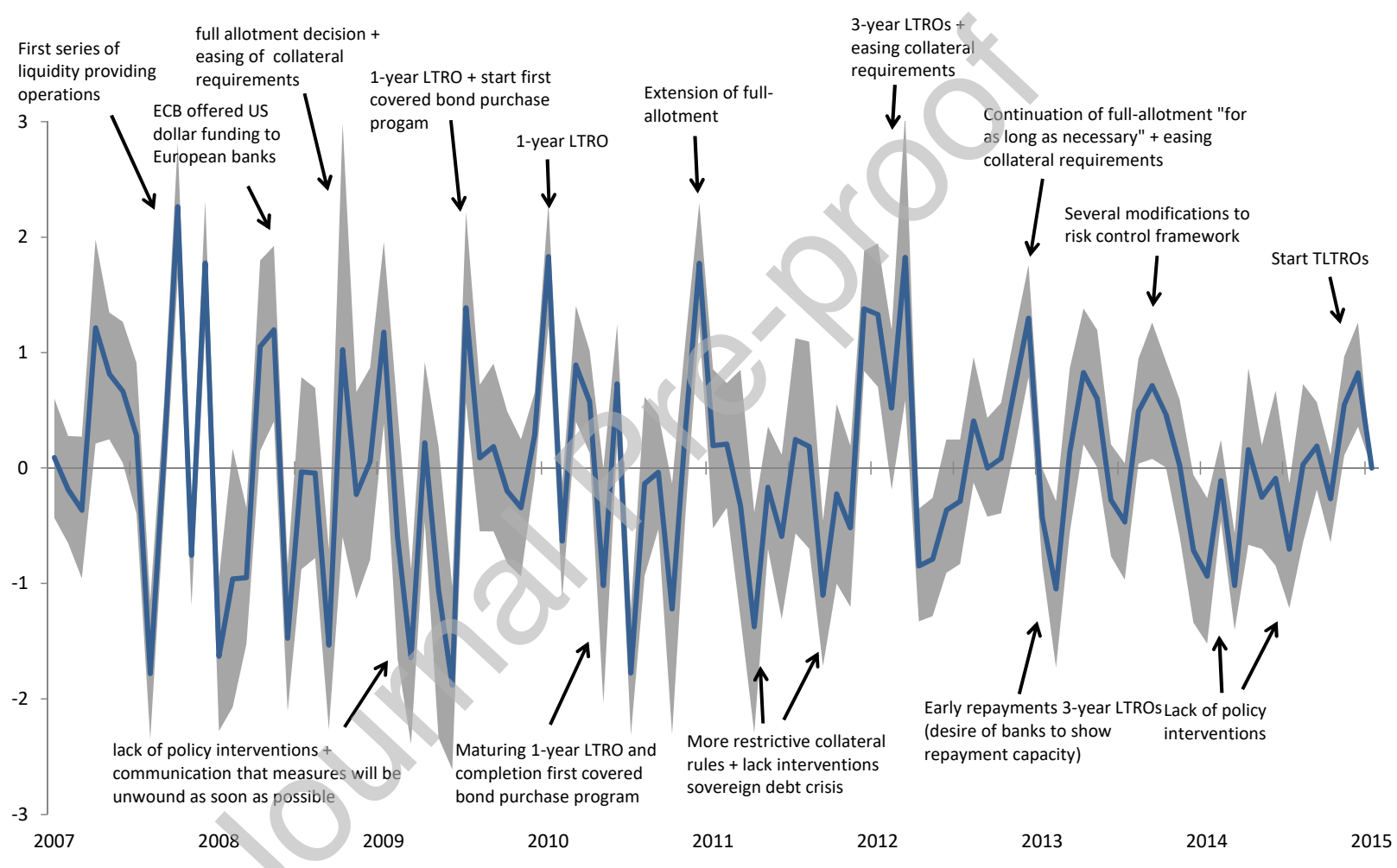

Note: figures show median shock, together with 16th and 84th percentiles of the posterior distribution. Shocks are measured in standard deviations. 
Figure 3 - Impulse responses to balance sheet shocks in the euro area (Boeckx et al. 2017)
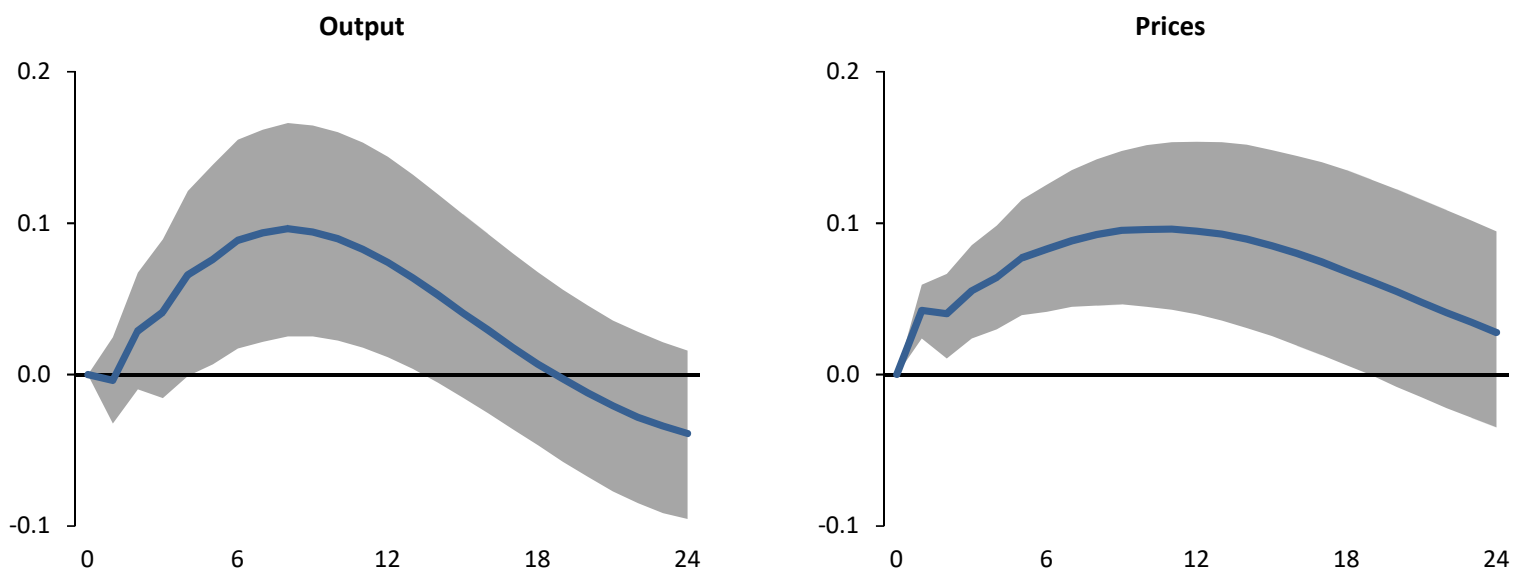

CISS
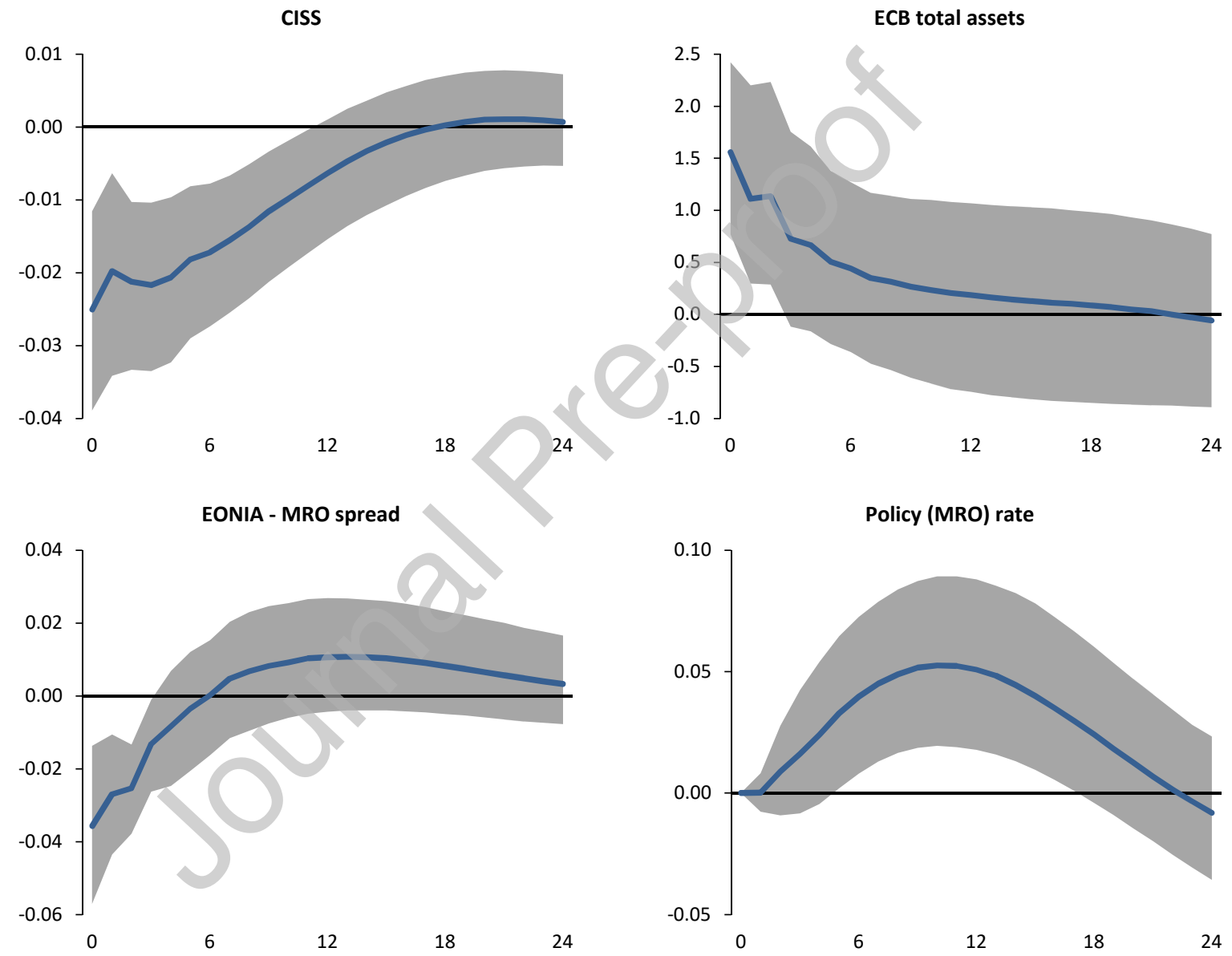

Note: figures show median responses, together with 16 th and 84 th percentiles of the posterior distribution; horizon is monthly 


\section{Journal Pre-proof}

Figure 4 - Impact of credit support policies on bank lending in the euro area: benchmark results

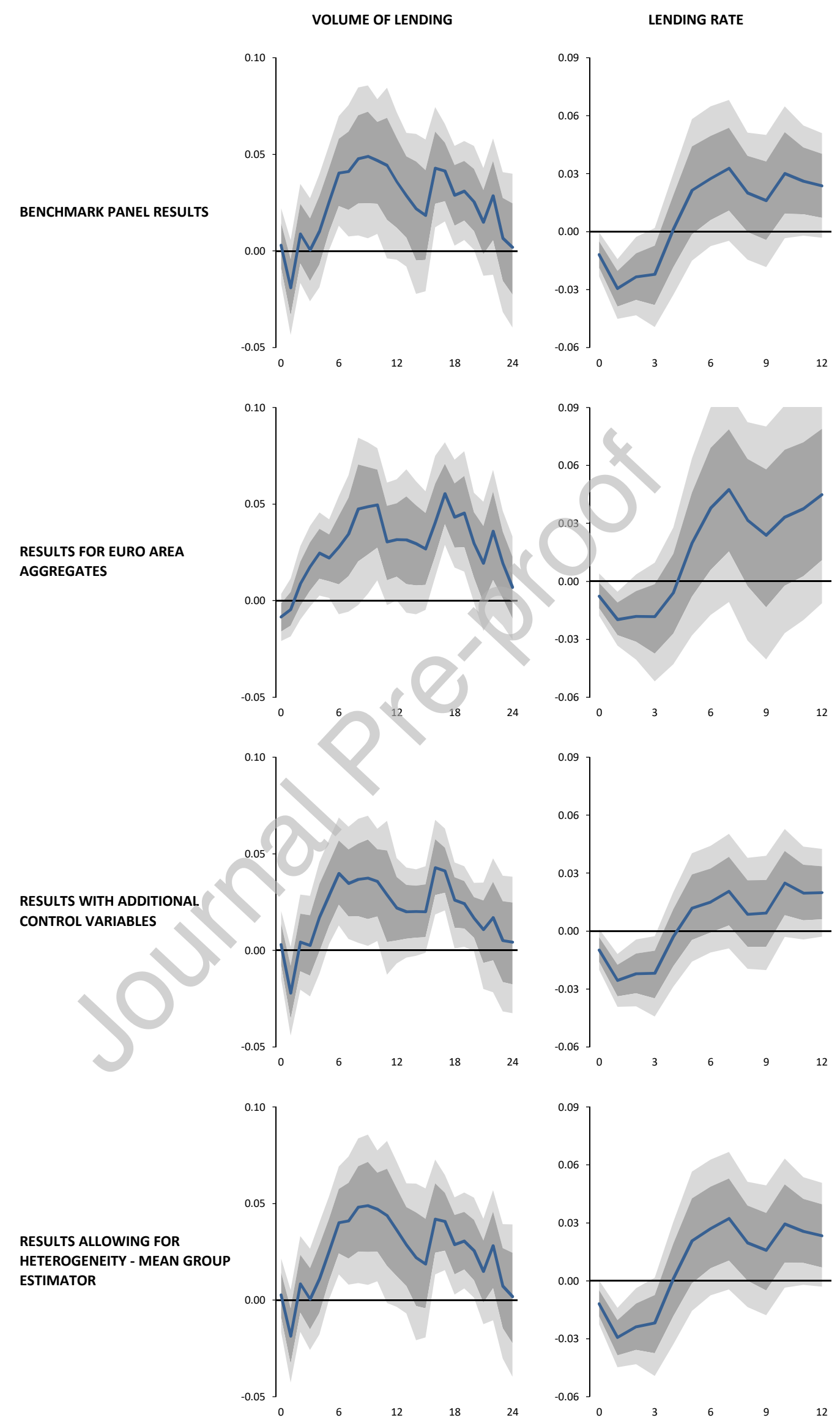

Note: horizon is monthly; 68 and 90 percent credible sets are clustered by time and adjusted for persistent common shocks 


\section{Journal Pre-proof}

Figure 5 - Bank characteristics and impact of credit support policies: benchmark results

VOLUME OF LENDING

Size

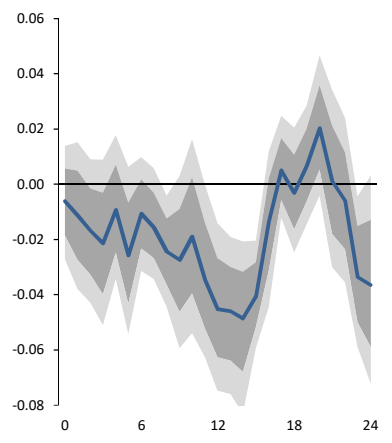

Retail funding

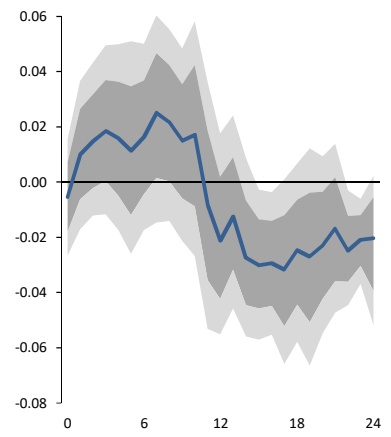

Liquidity

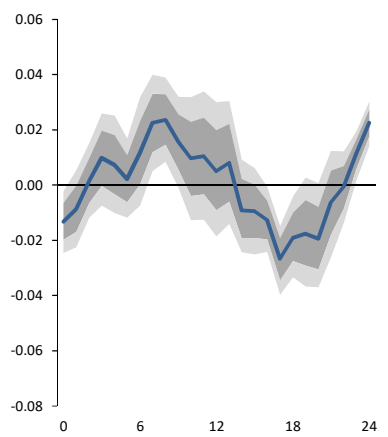

Capital

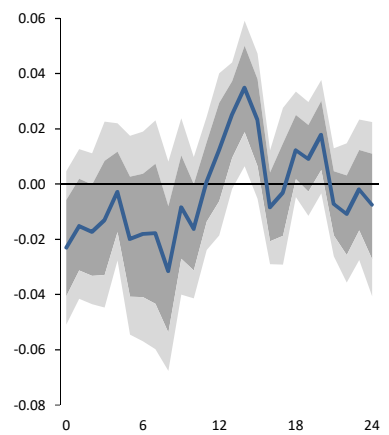

\section{LENDING RATE}

Size

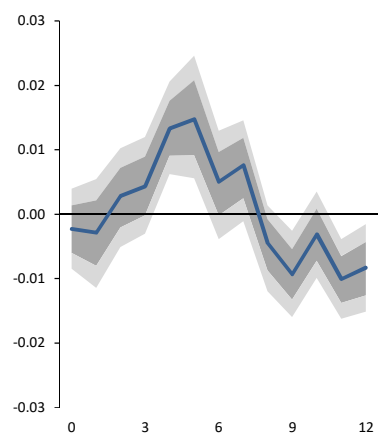

Retail funding

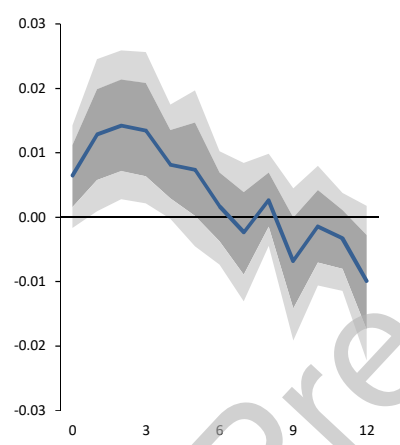

Liquidity

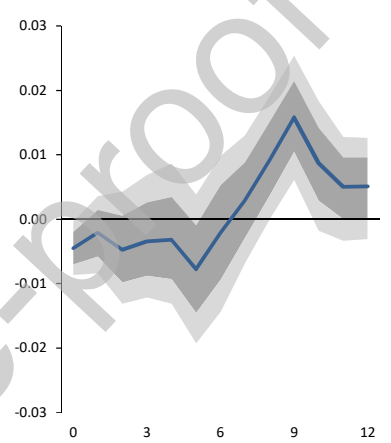

Capital

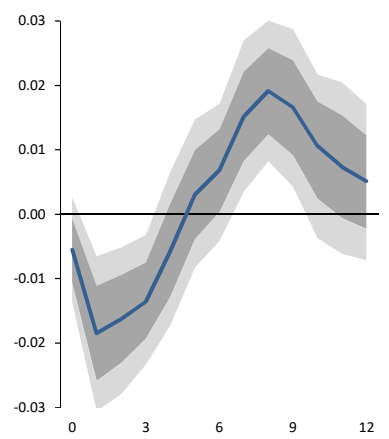

Note: horizon is monthly; 68 and 90 percent credible sets are clustered by time and adjusted for persistent common shocks 


\section{Journal Pre-proof}

Figure 6 - Bank characteristics and impact of credit support policies on the volume of lending: robustness analysis

Size

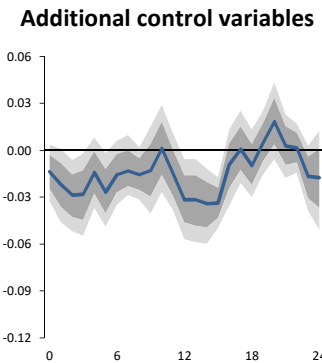

Retail funding

Capital
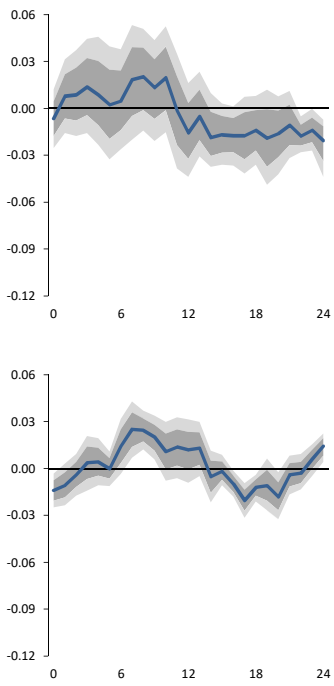
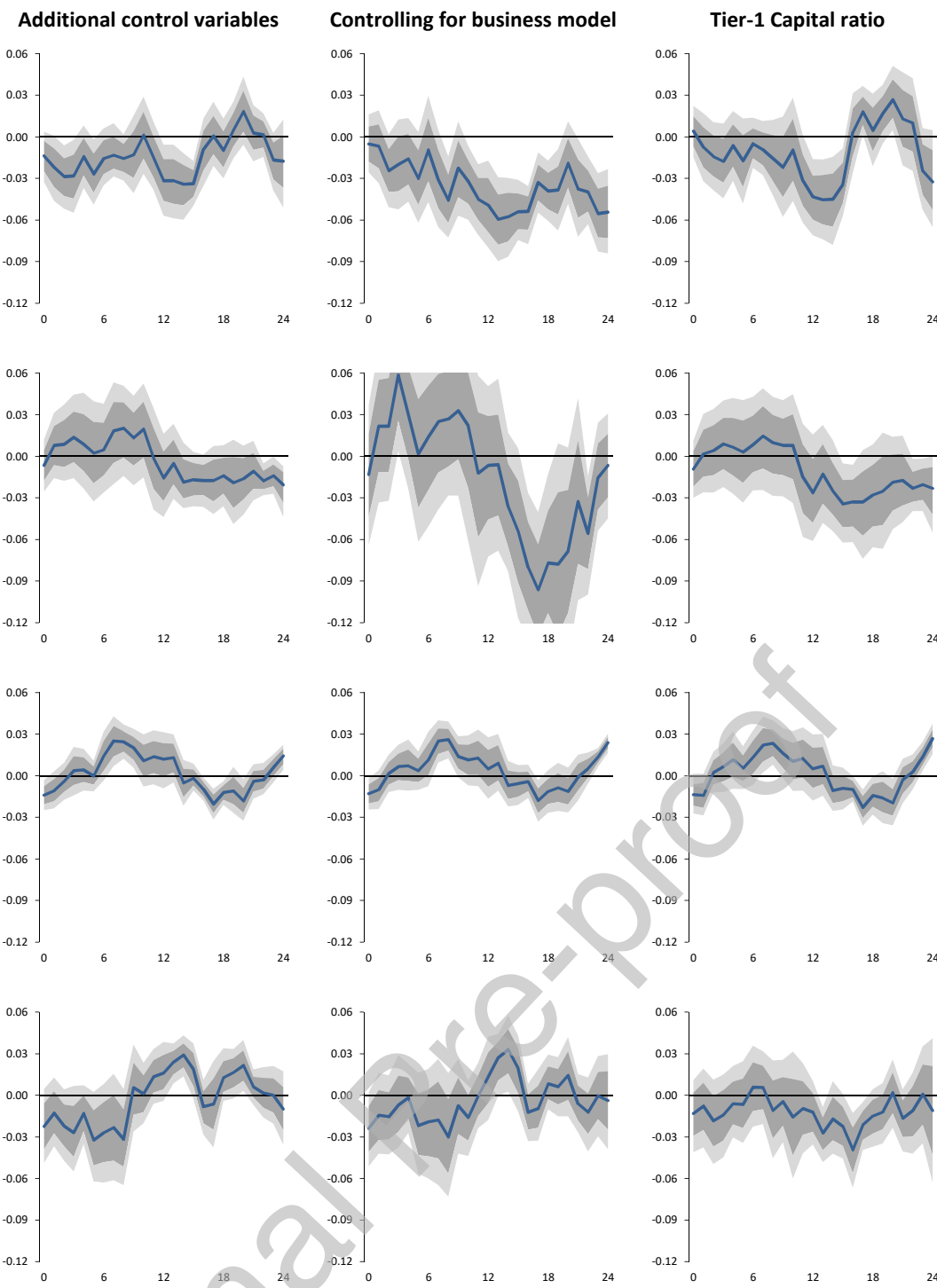
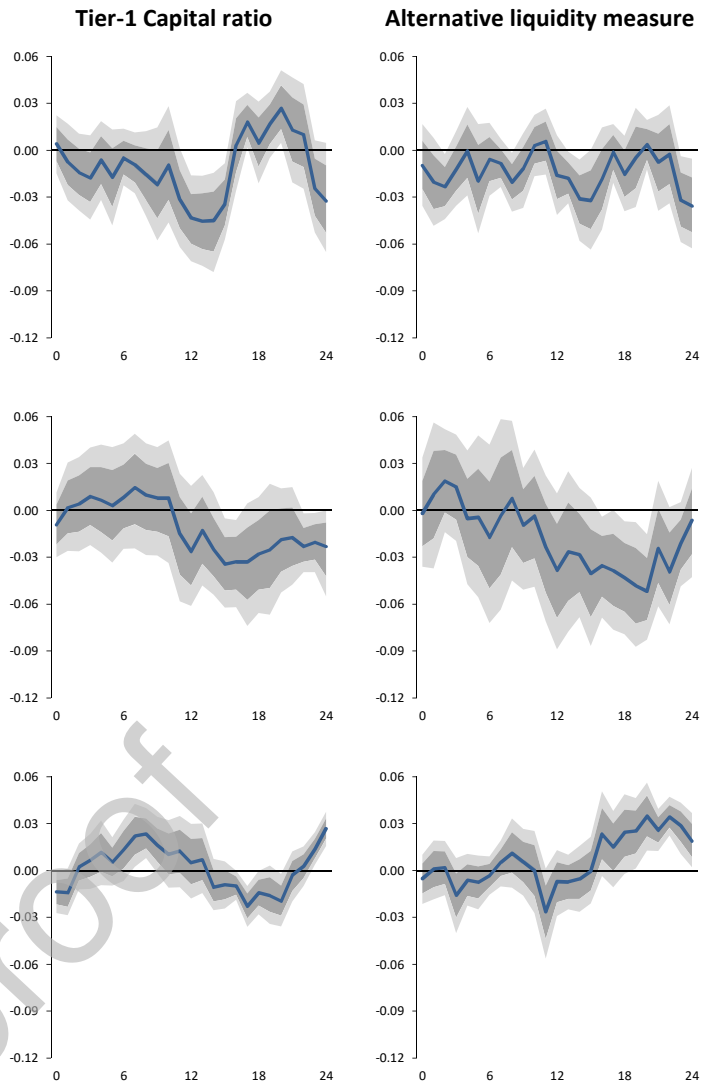

Alternative liquidity measure
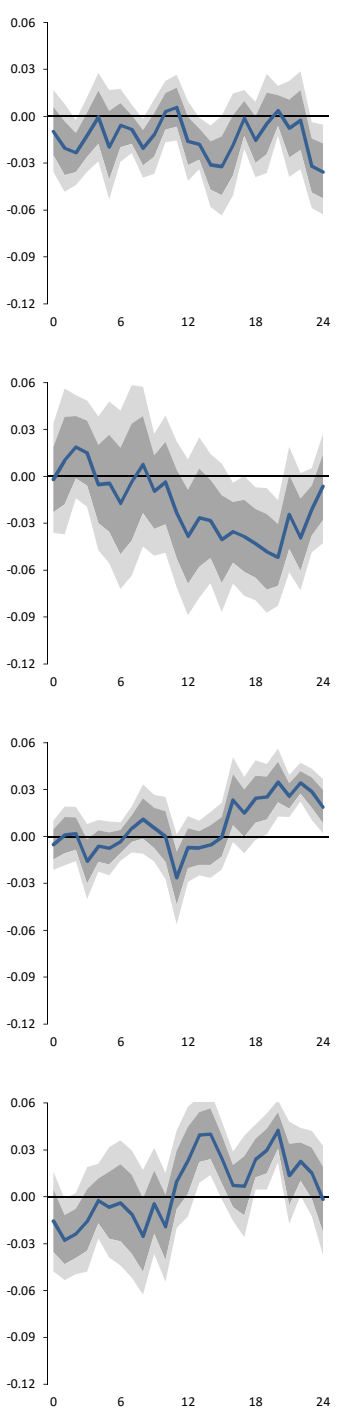

Note: horizon is monthly; 68 and 90 percent credible sets are clustered by time and adjusted for persistent common shocks 


\section{Journal Pre-proof}

Figure 7 - Bank characteristics and impact of credit support policies on lending rates: robustness analysis

Size

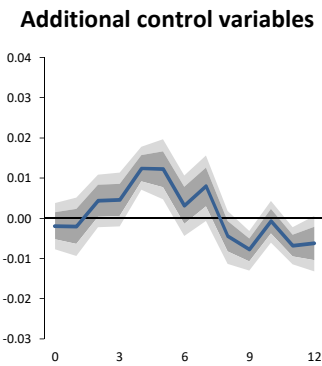

Retail funding

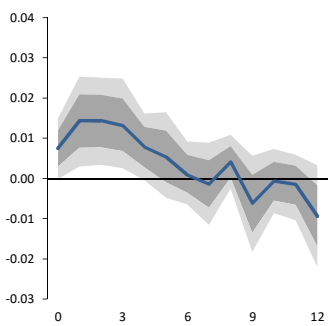

Liquidity

Capital
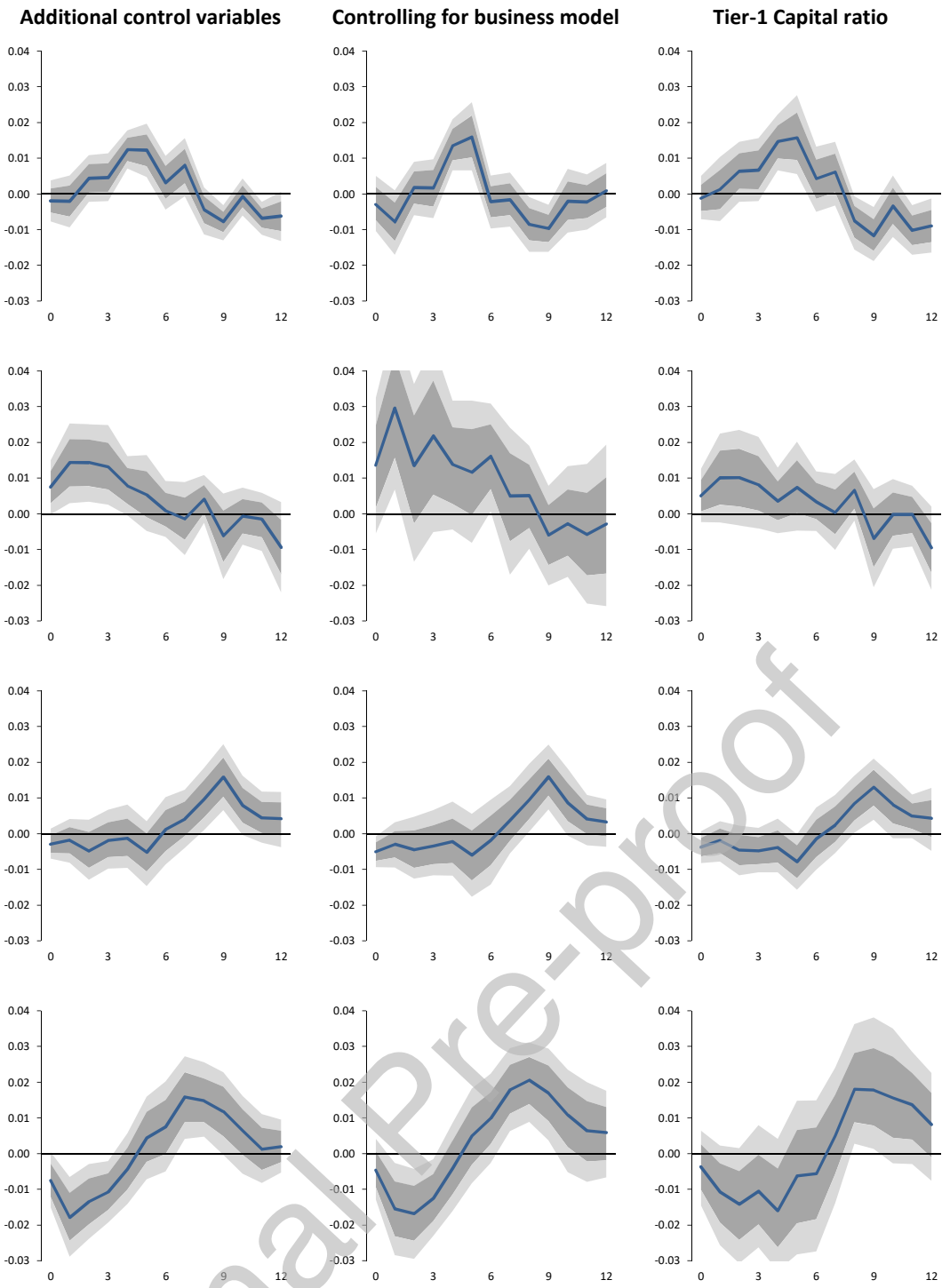

Alternative liquidity measure
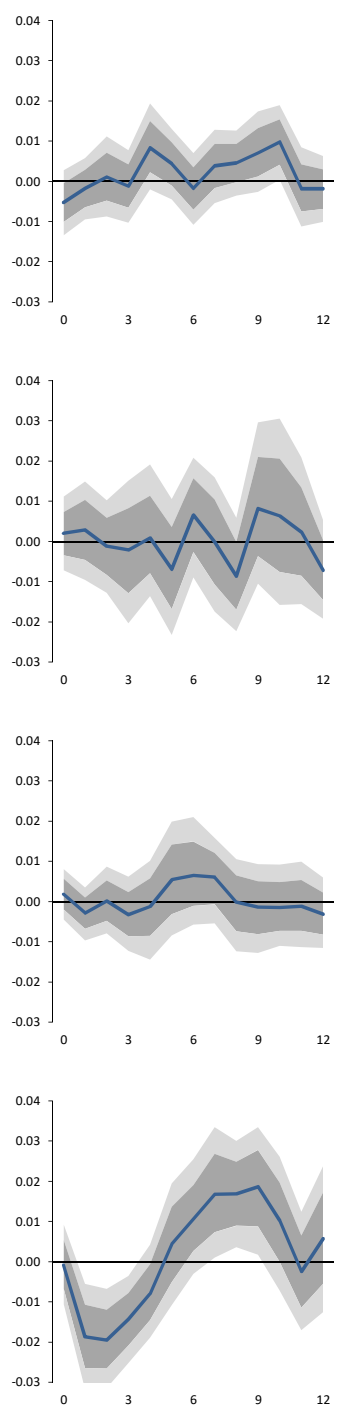

Note: horizon is monthly; 68 and 90 percent credible sets are clustered by time and adjusted for persistent common shocks 


\section{Journal Pre-proof}

Figure 8 - The role of bank capital: estimation with dummy for low-capitalized banks

VOLUME OF LENDING
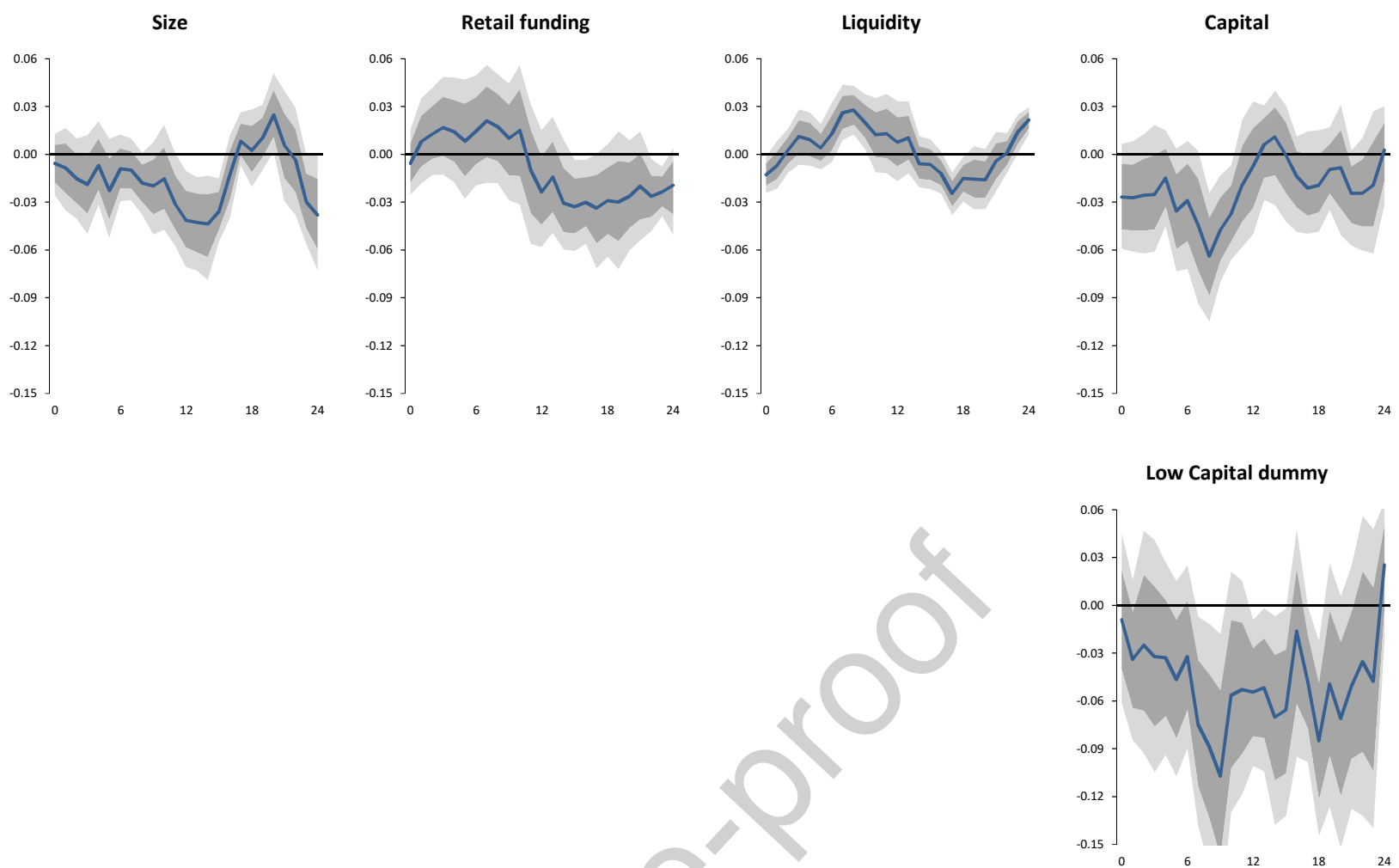

\section{LENDING RATE}

Size

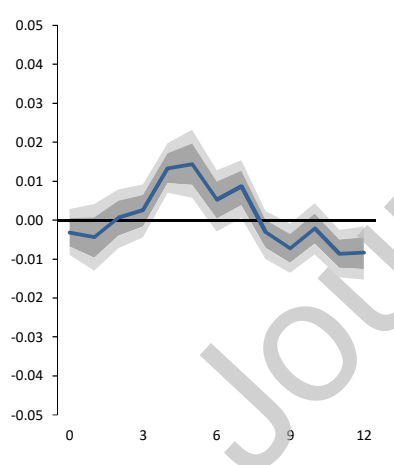

Retail funding

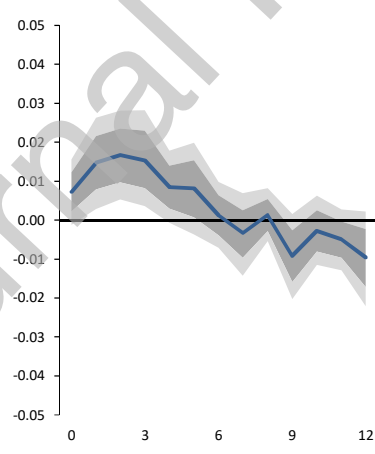

Liquidity

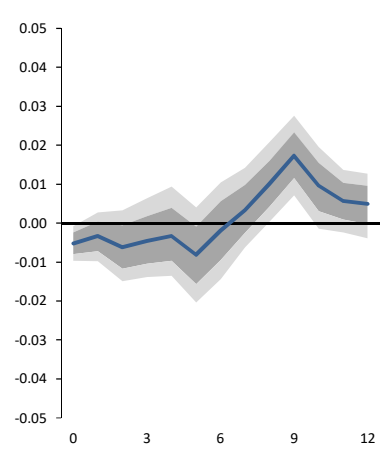

Capital

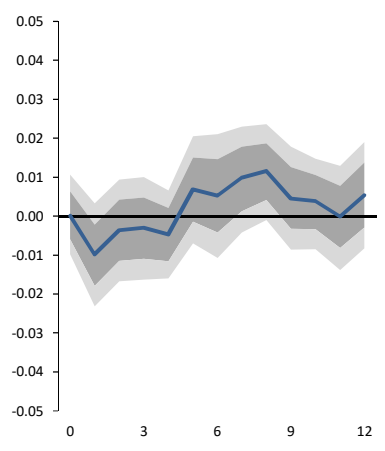

Low Capital dummy

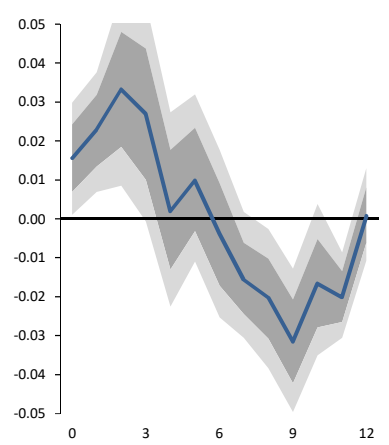

Note: horizon is monthly; 68 and 90 percent credible sets are clustered by time and adjusted for persistent common shocks 
Figure 9 - Estimations with dummy for low-capitalized banks: robustness analysis for the volume of lending

Size
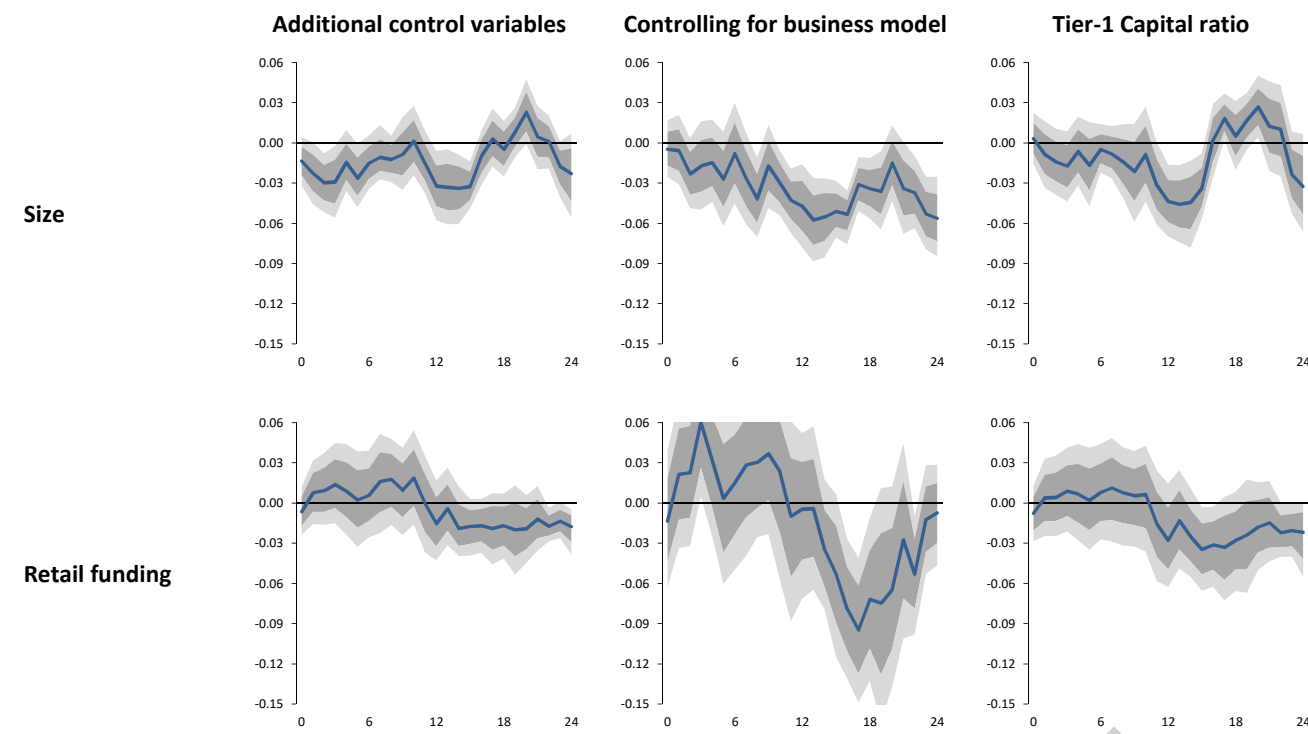

Alternative liquidity measure
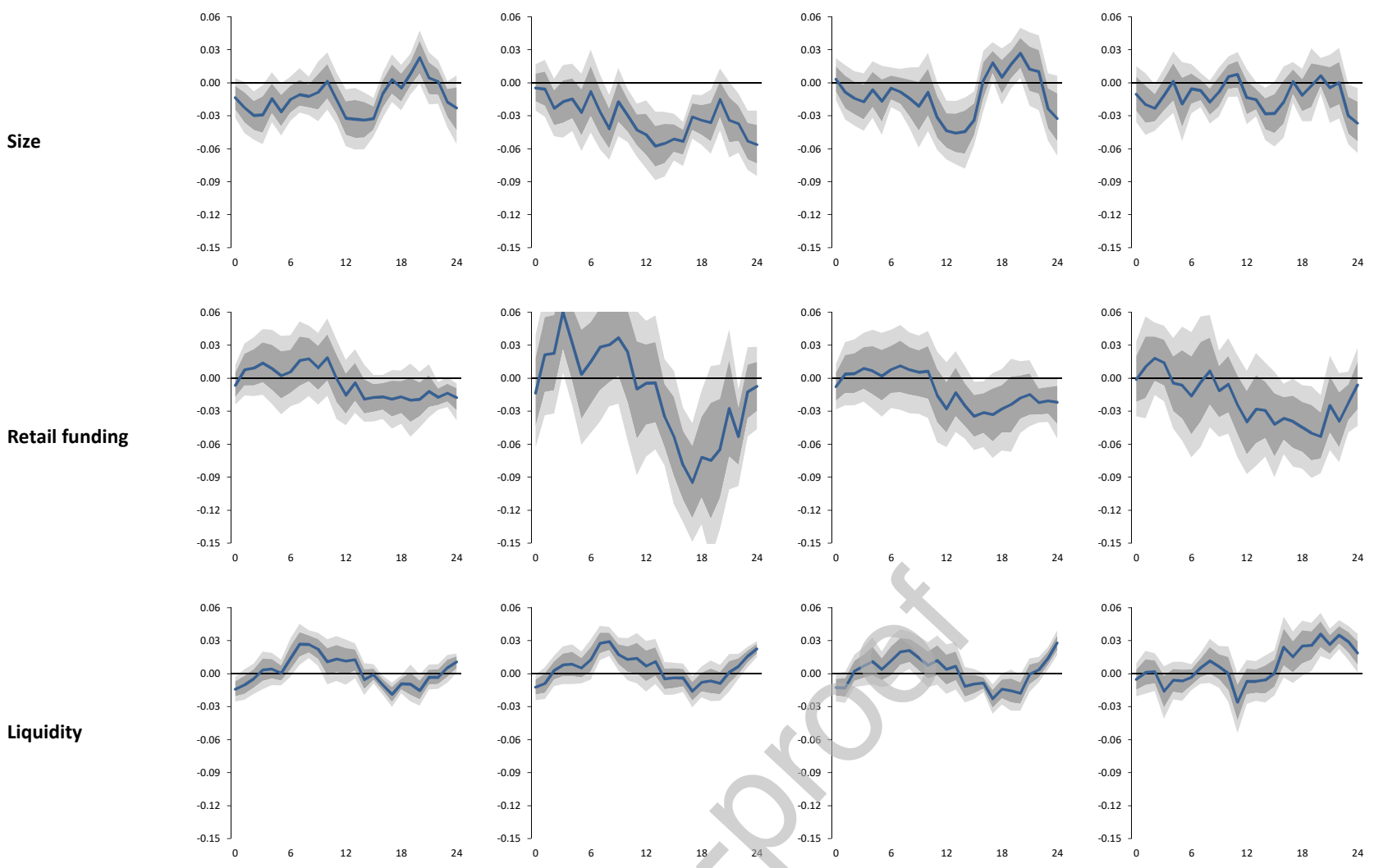

Capital

Low capital
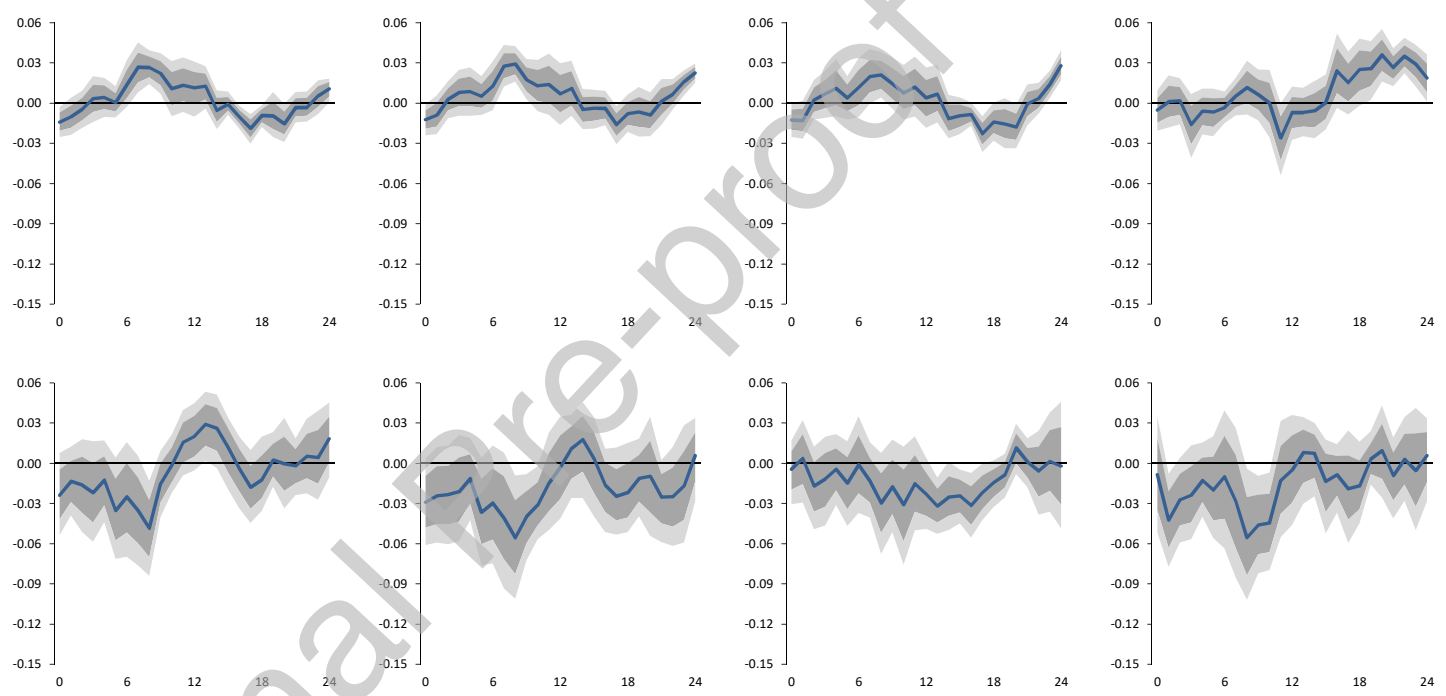

dummy
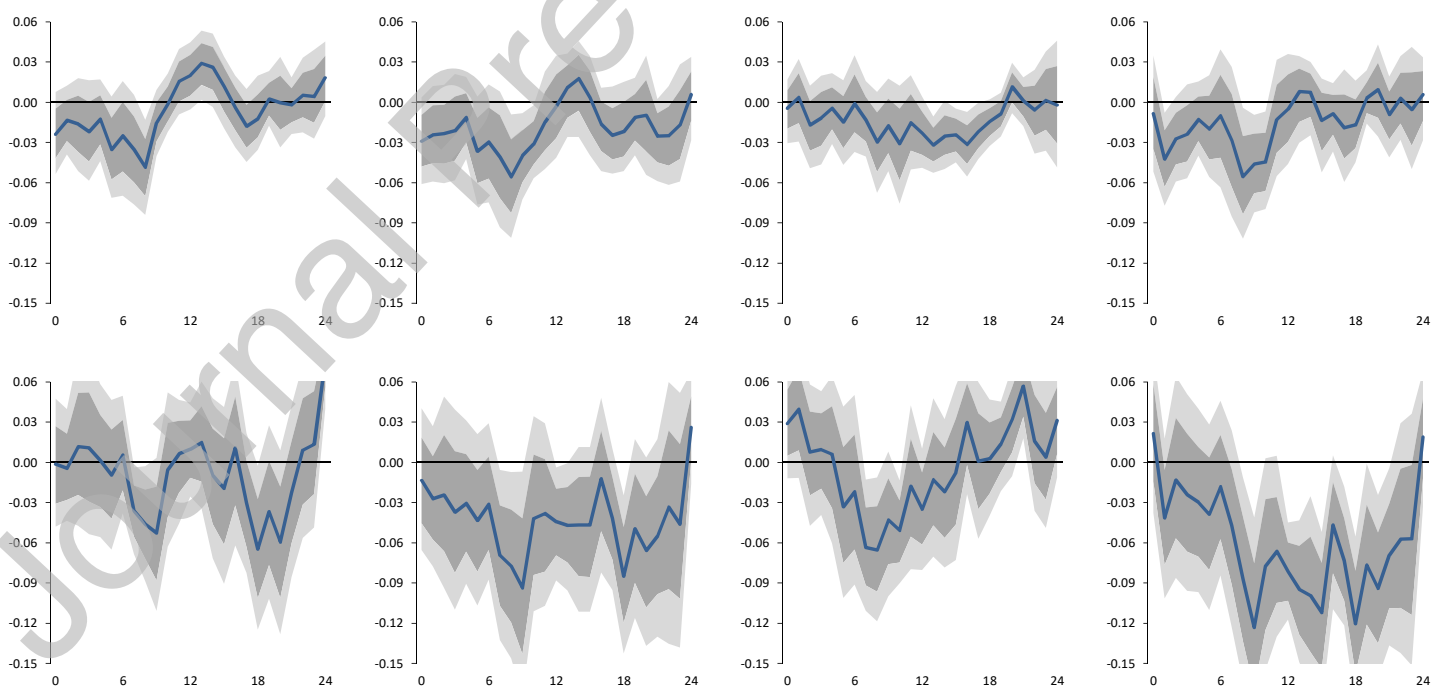

Note: horizon is monthly; 68 and 90 percent credible sets are clustered by time and adjusted for persistent common shocks 
Figure 10 - Estimations with dummy for low-capitalized banks: robustness analysis for bank lending rates

Size

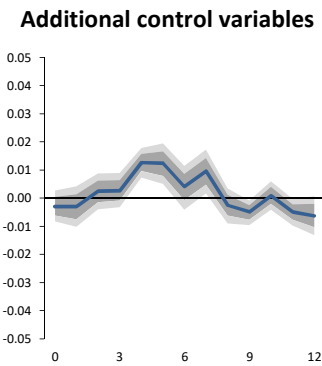

Retail funding

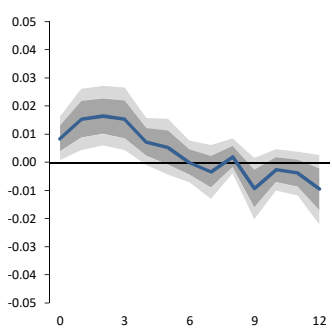

Liquidity

Capital

Low capital dummy
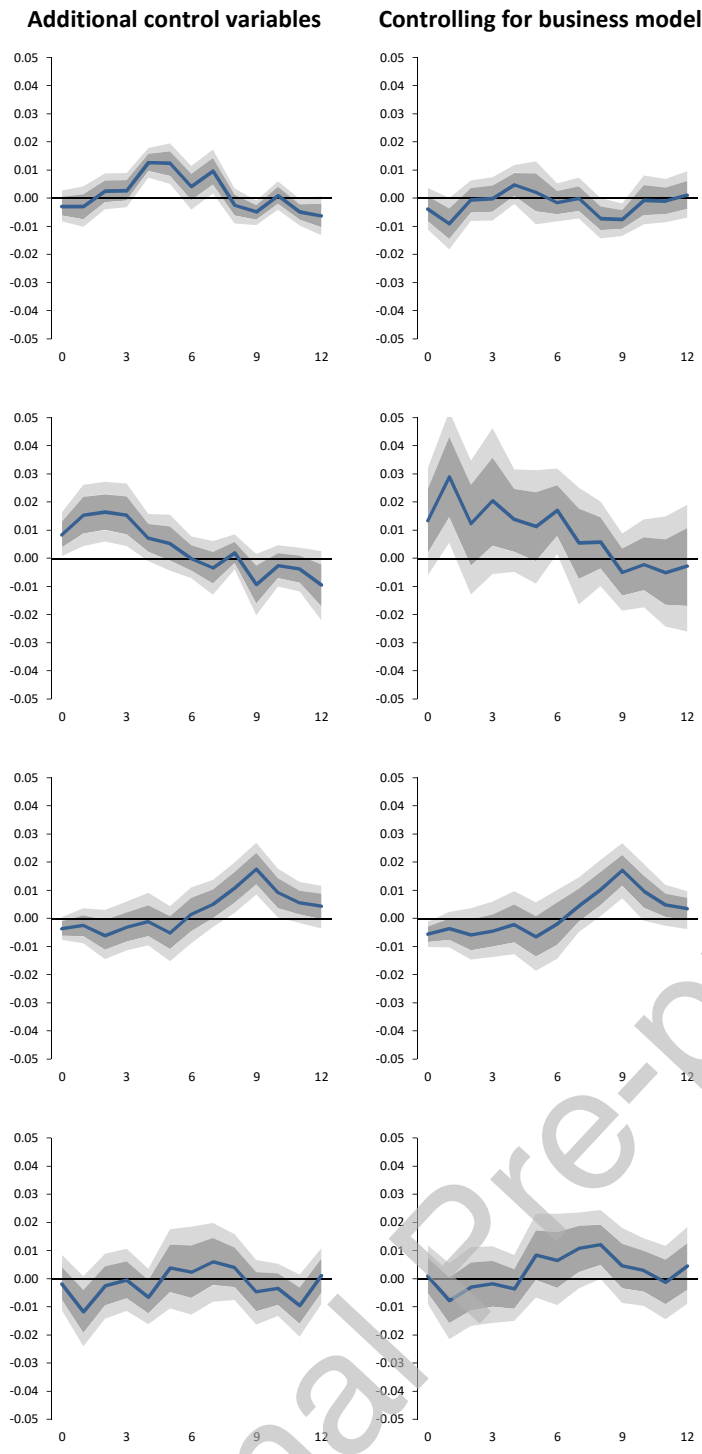

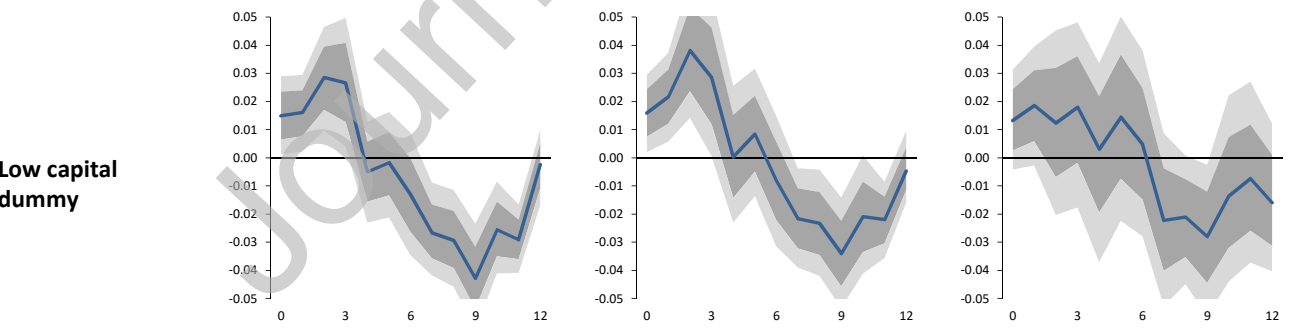

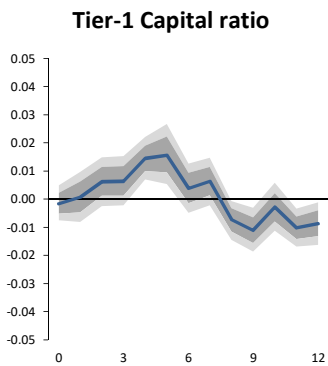
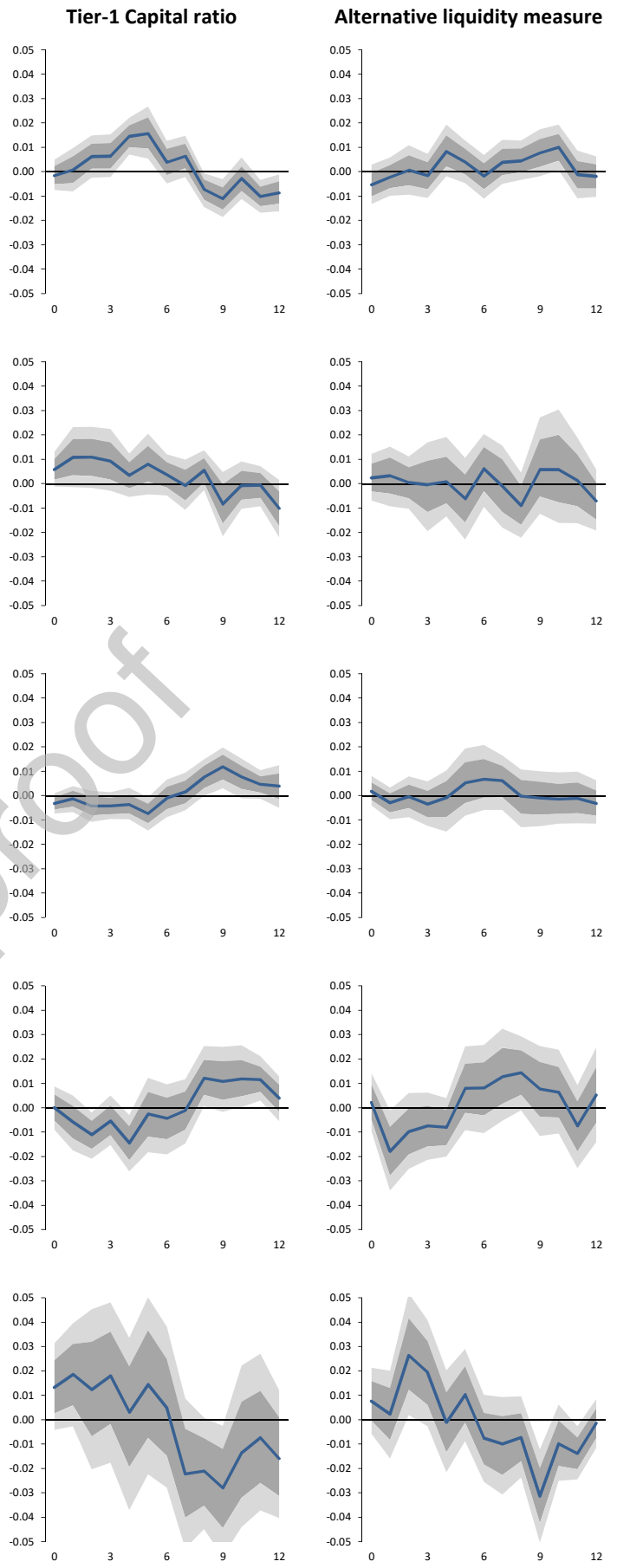

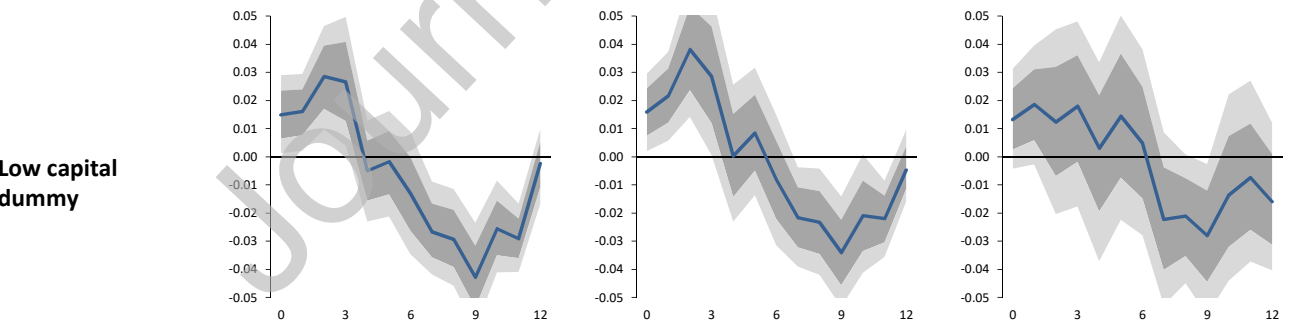

Note: horizon is monthly; 68 and 90 percent credible sets are clustered by time and adjusted for persistent common shocks 
Figure 11 - The role of bank capital: estimations with interaction effects

VOLUME OF LENDING
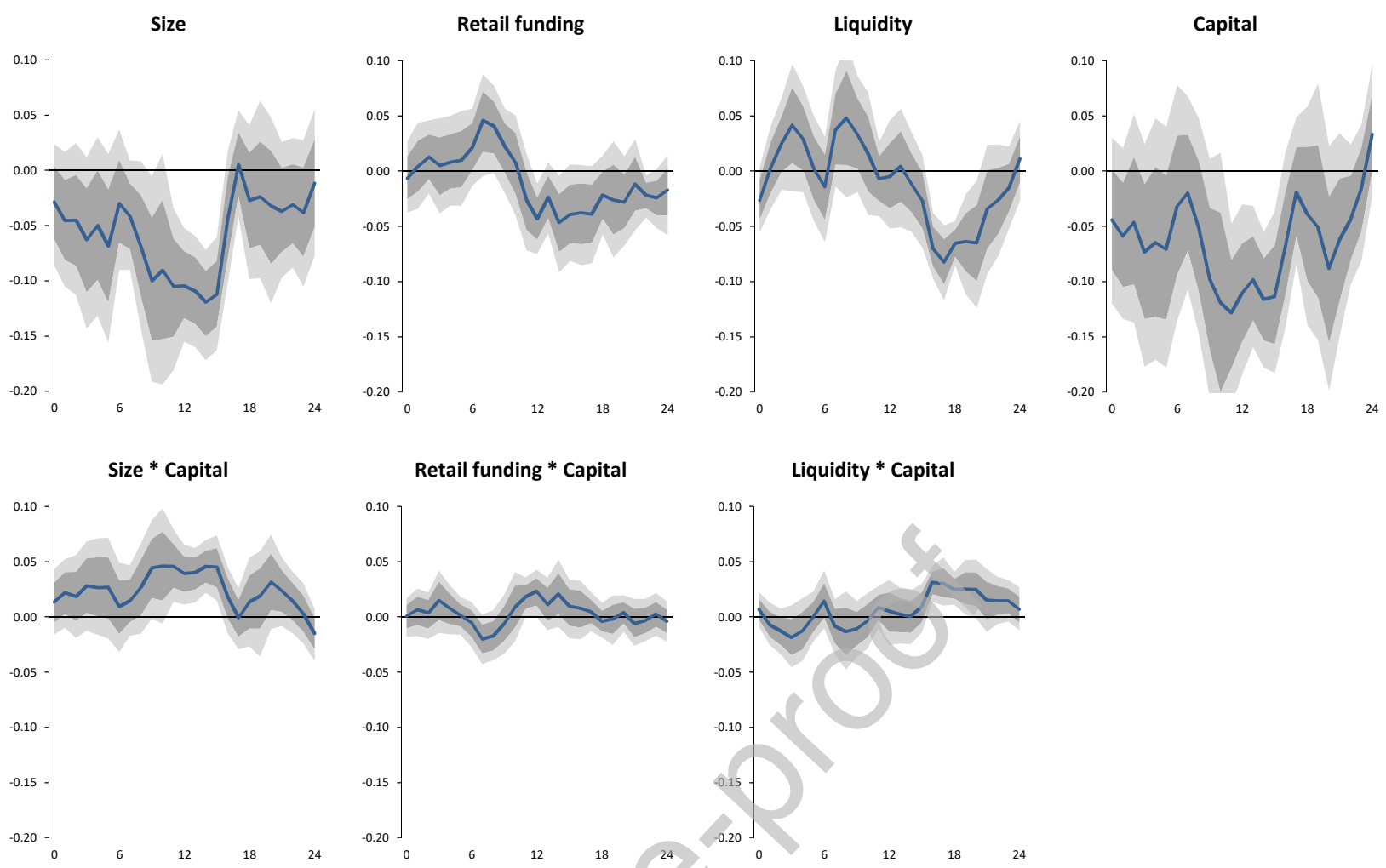

\section{LENDING RATE}
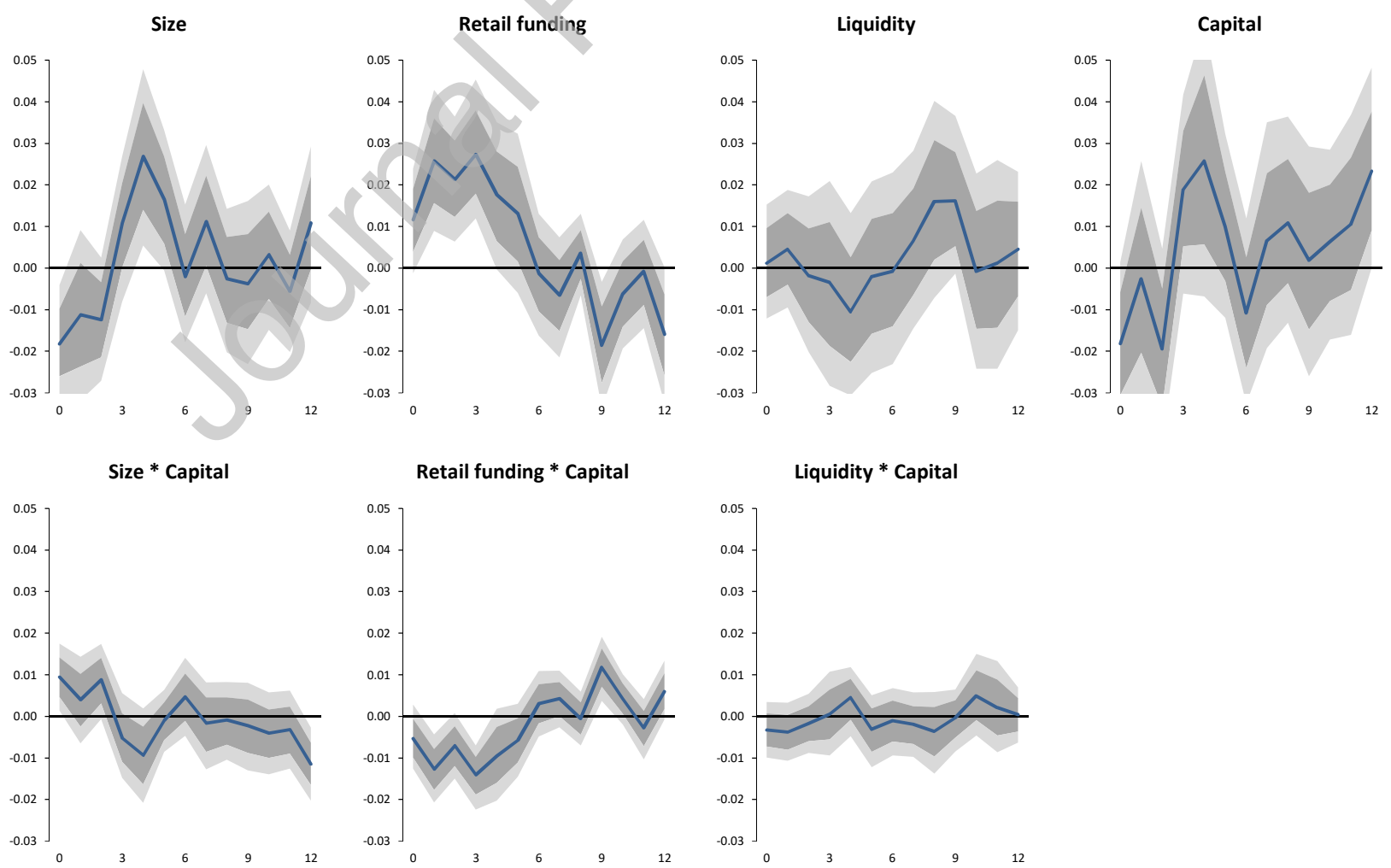

Note: horizon is monthly; 68 and 90 percent credible sets are clustered by time and adjusted for persistent common shocks 
Figure 12 - Estimations with interaction effects: robustness analysis for the volume of lending

Size

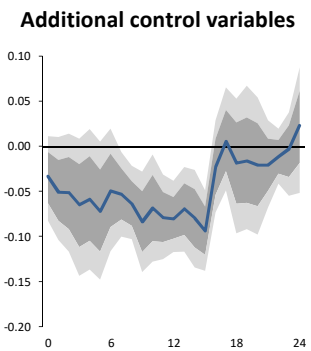

Liquidity

Capital

Size * Capita

Retail funding * Capital

Liquidity * Capital
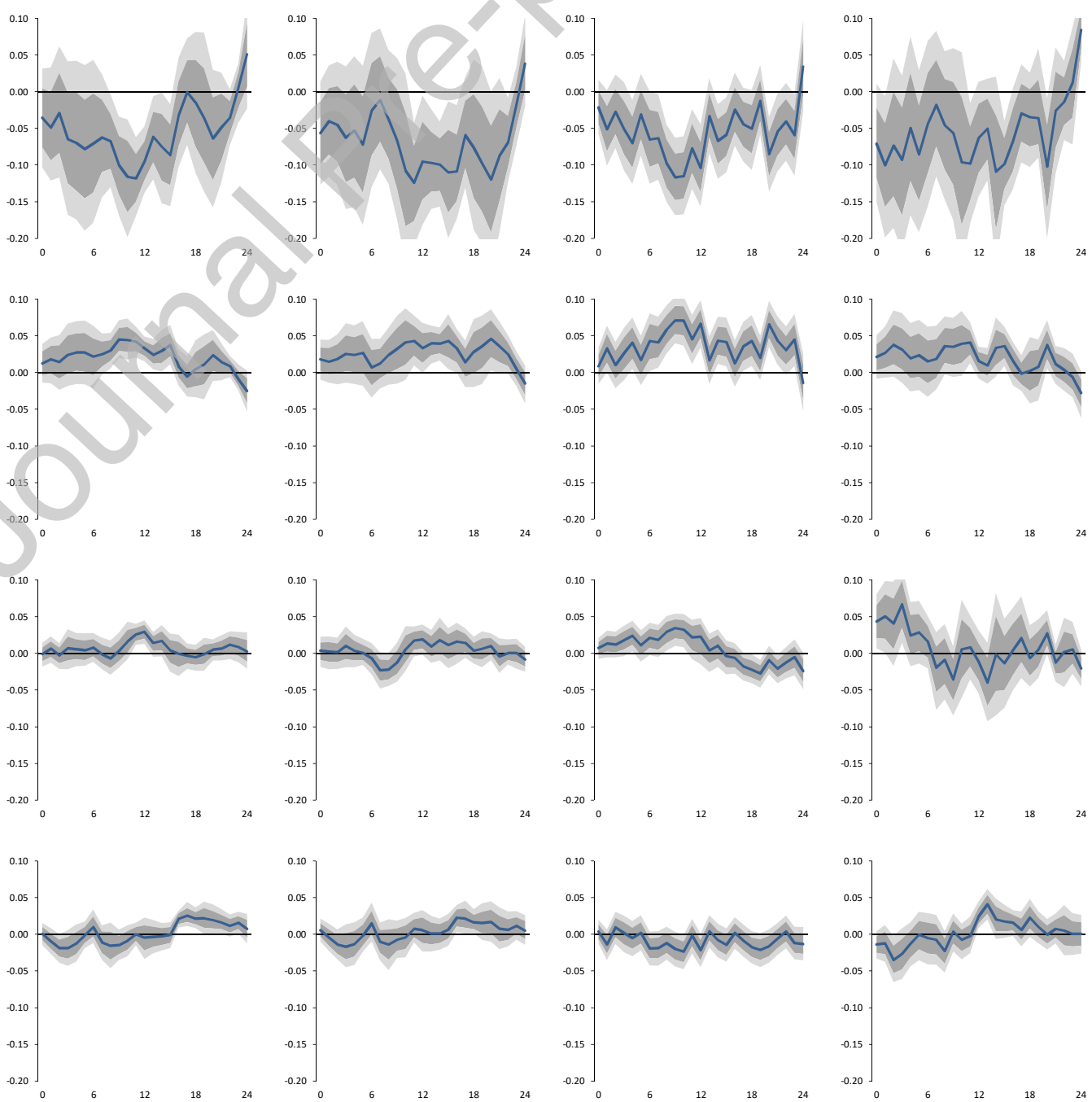
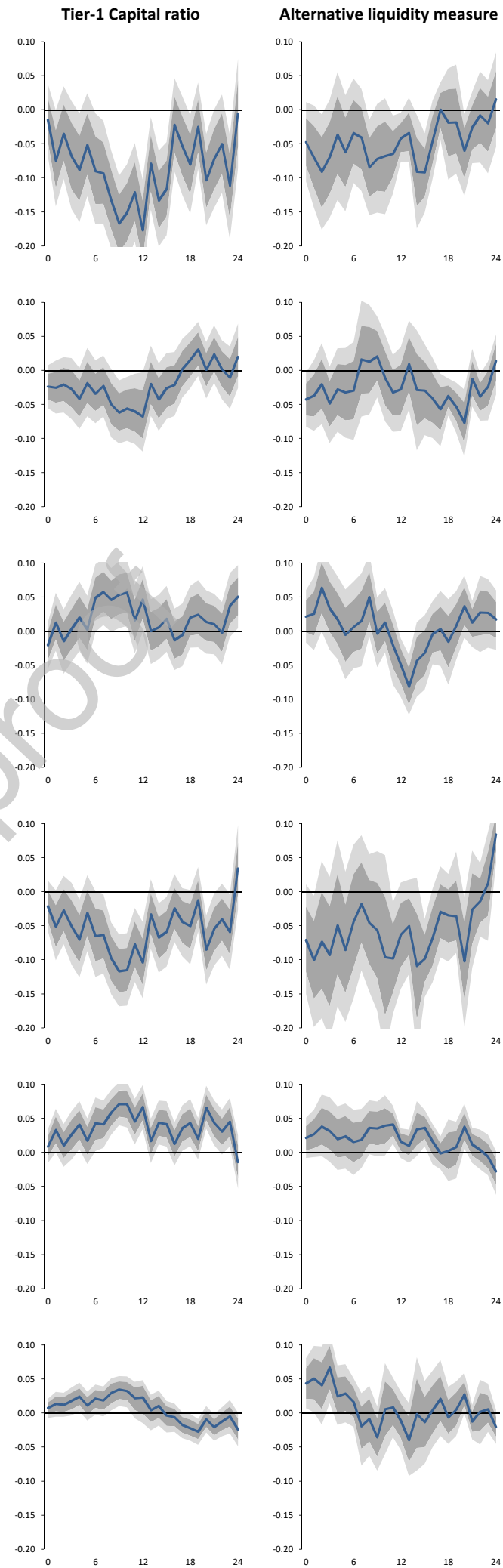

Alternative liquidity measure
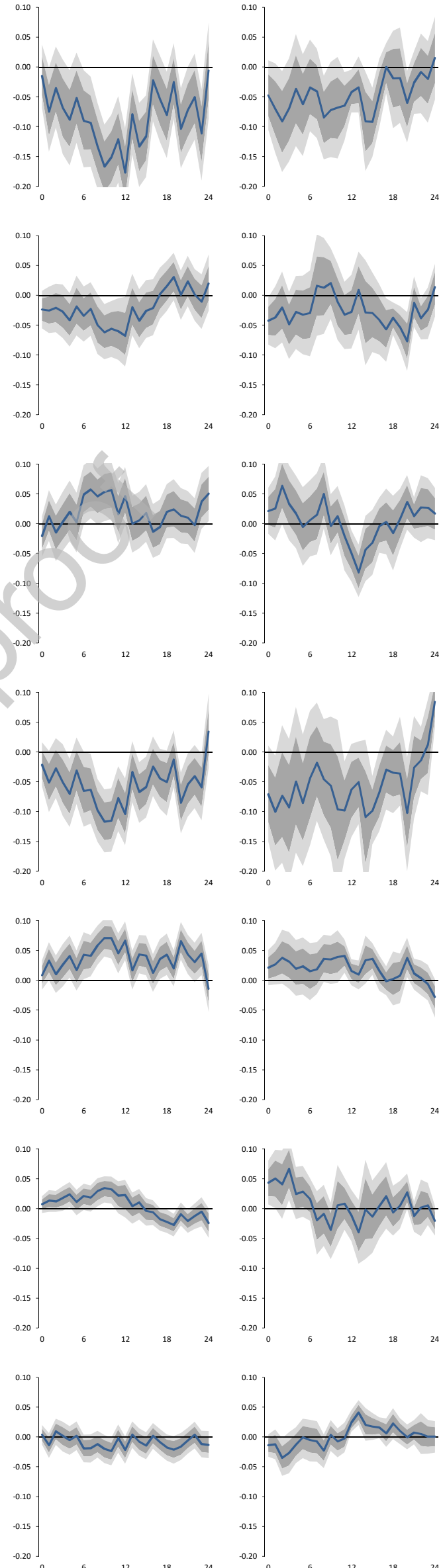
Figure 13 - Estimations with interaction effects: robustness analysis for bank lending rates

Size

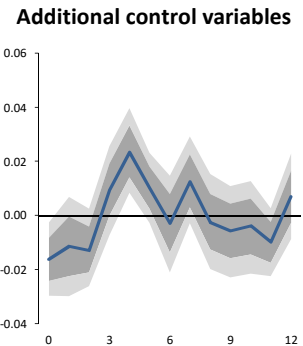

Retail funding

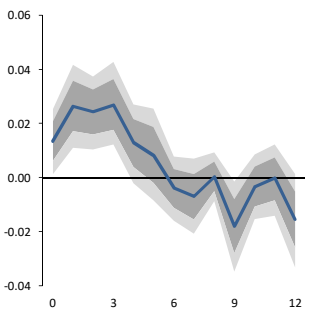

Liquidity

Capital

Size * Capital

Retail funding * Capital
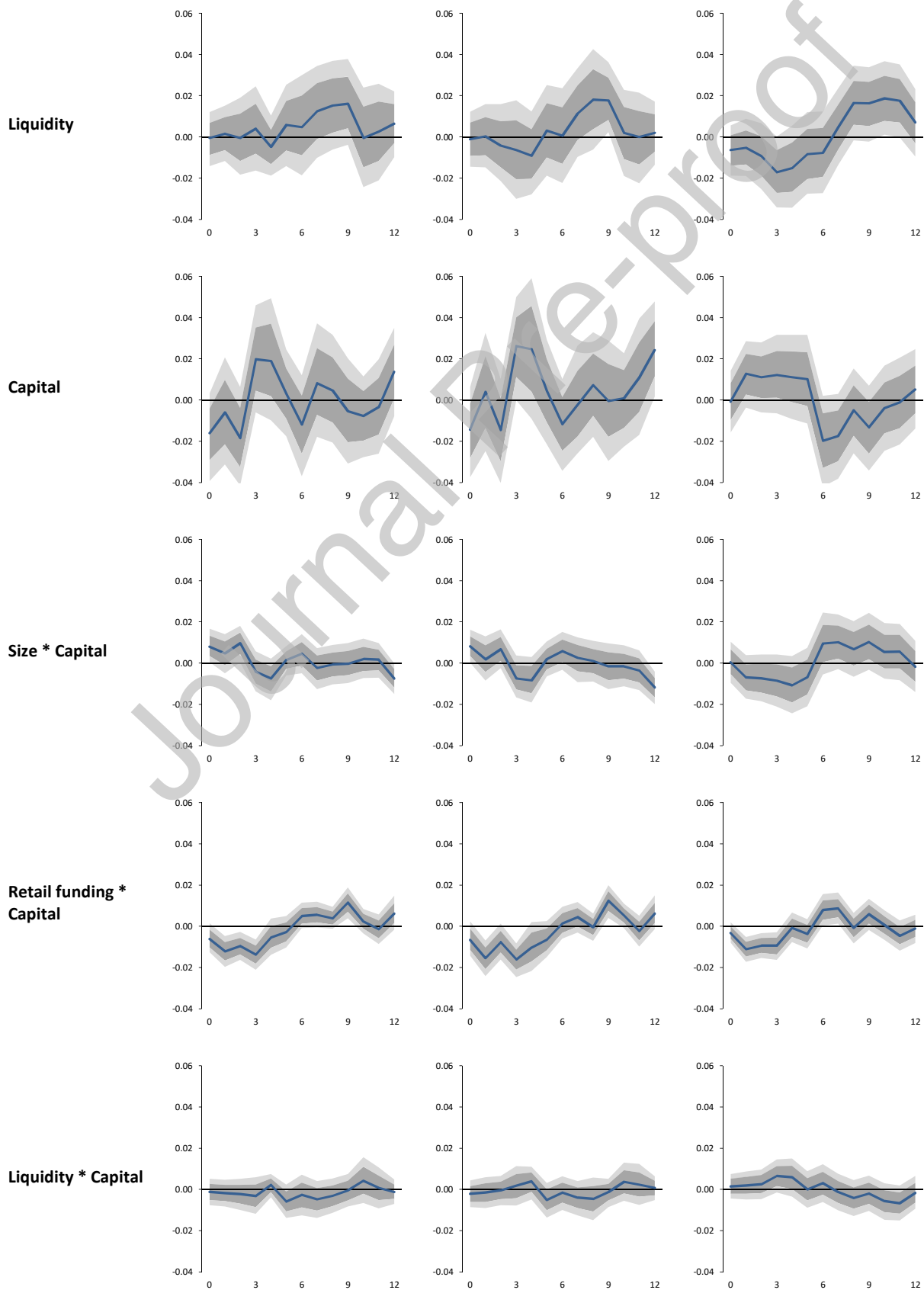
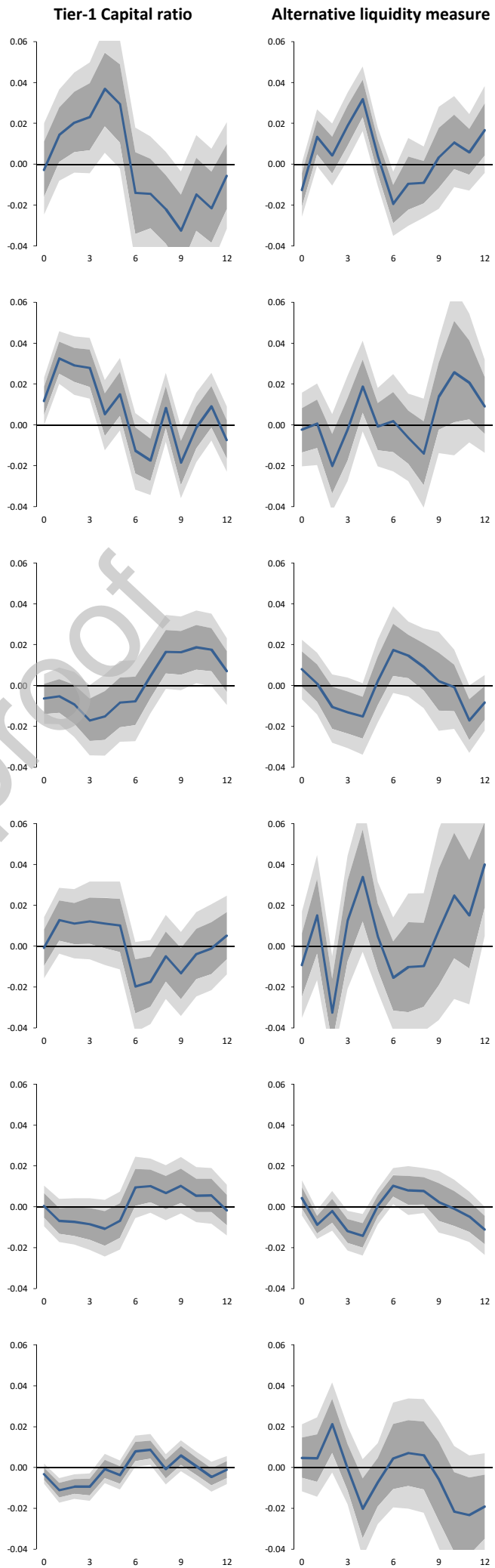

Alternative liquidity measure
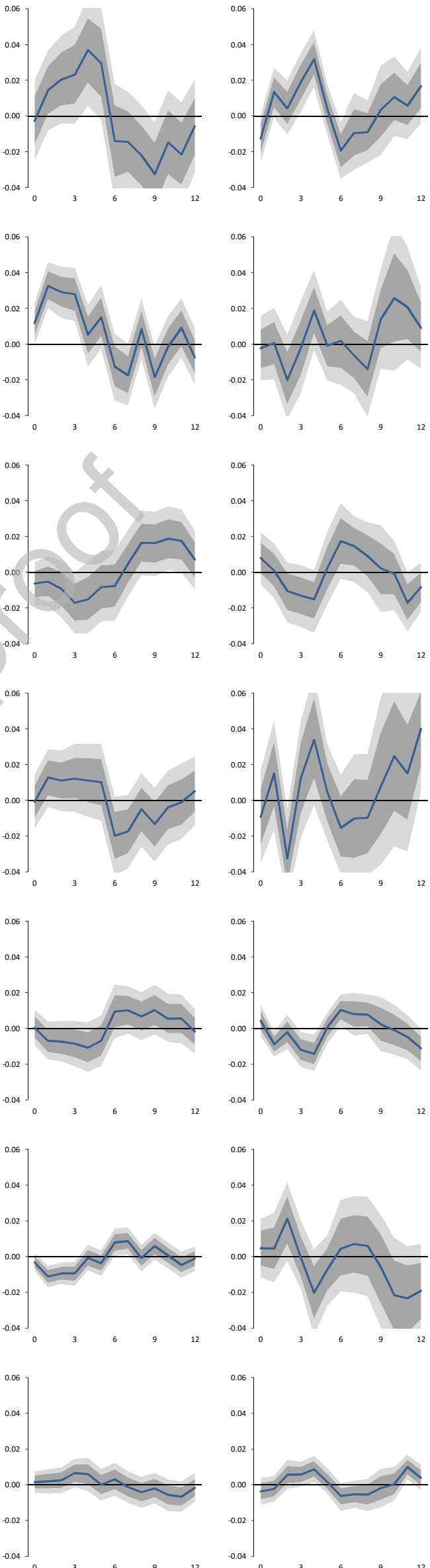


\section{Journal Pre-proof}

Figure A1 - Impact of credit support policies on bank lending in the euro area: smoothed IRFs
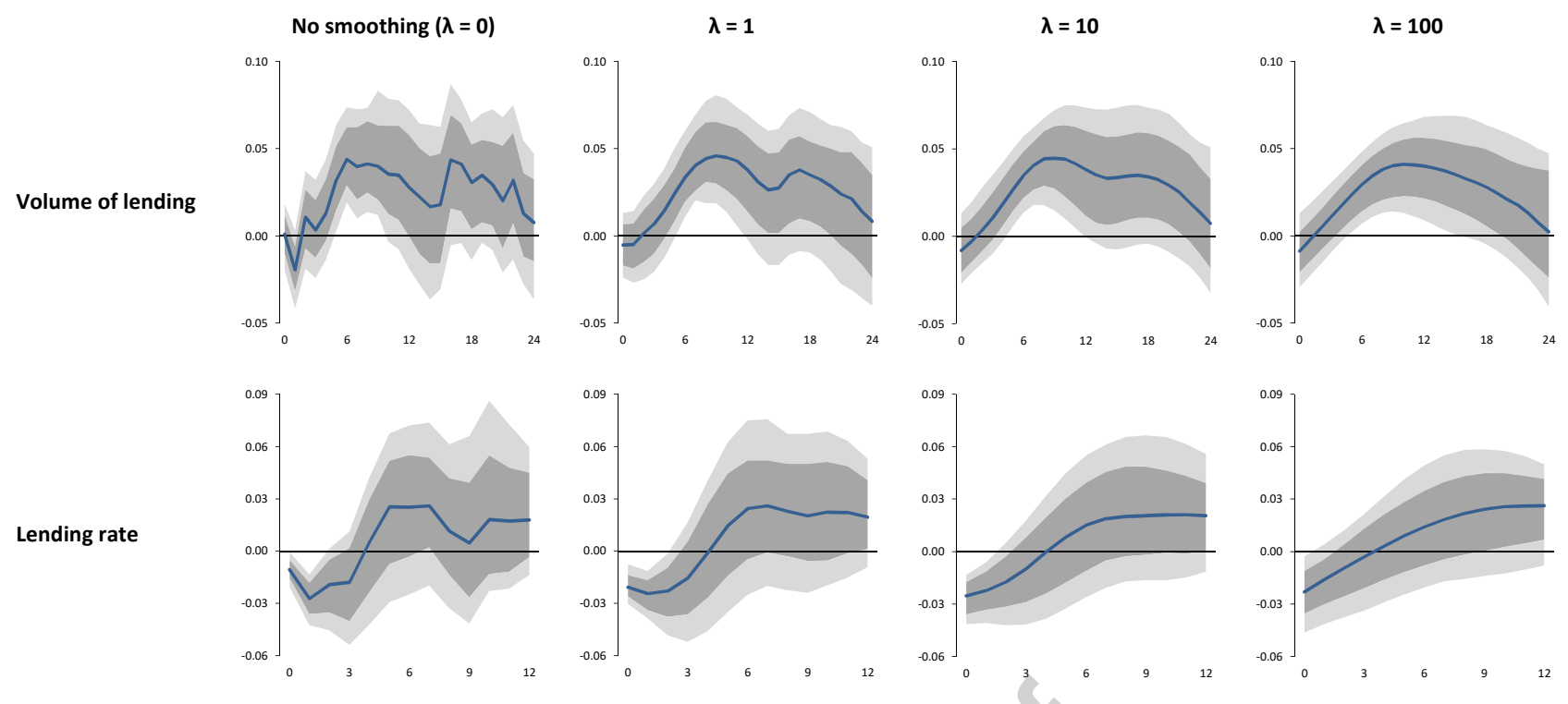

Note: horizon is monthly; 68 and 90 percent bootstrapped credible sets clustered by time and adjusted for persistent common shocks; $\lambda=$ imposed degree of smoothness 


\section{Journal Pre-proof}

Figure A2 - Bank characteristics and impact of credit support policies on the volume of lending: smoothed IRFs

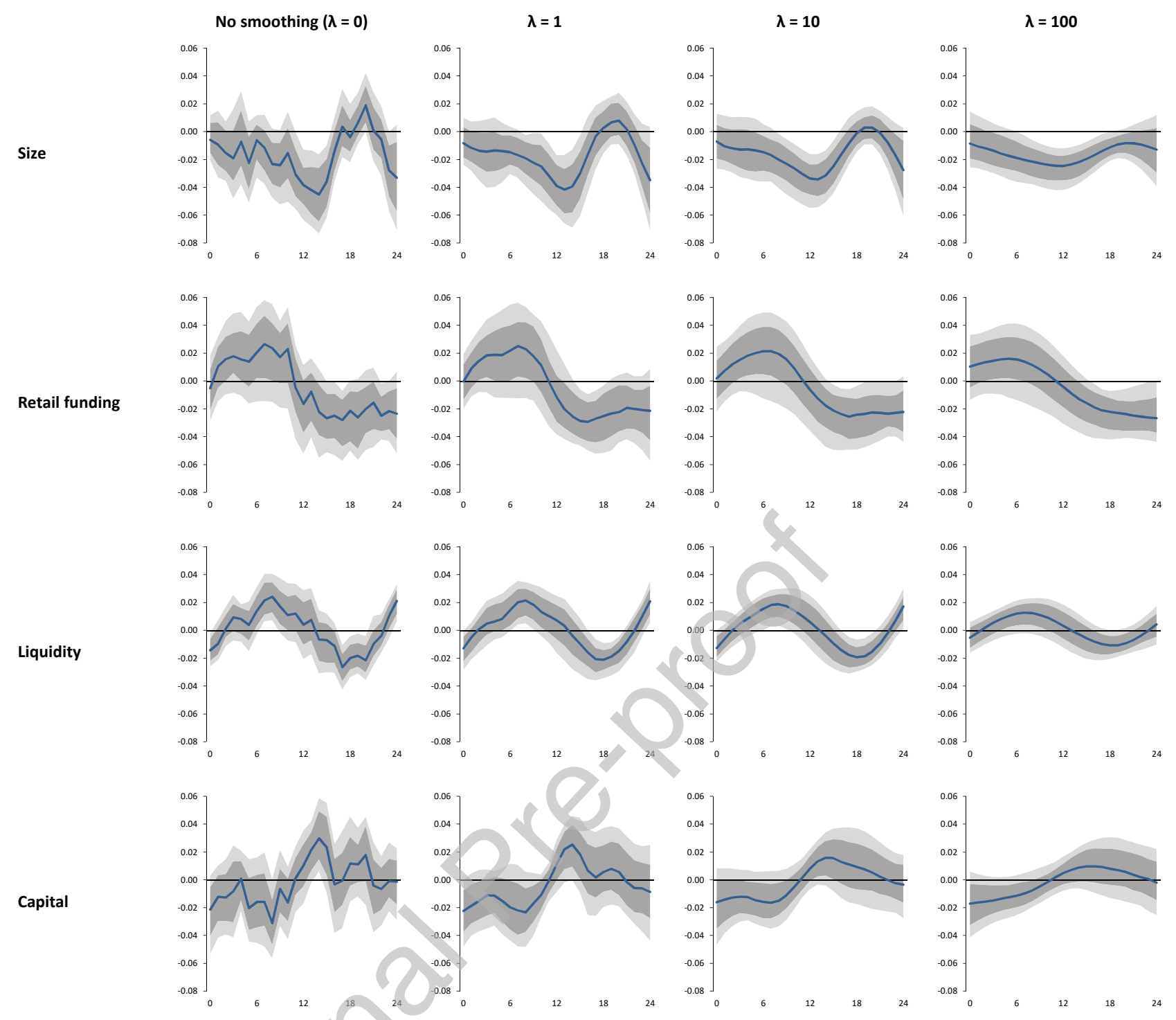

Note: horizon is monthly; 68 and 90 percent bootstrapped credible sets clustered by time and adjusted for persistent common shocks; $\lambda=$ imposed degree of smoothness 


\section{Journal Pre-proof}

Figure A3 - Bank characteristics and impact of credit support policies on lending rates: smoothed IRFs

Size

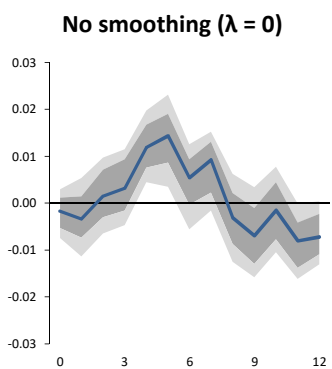

$\lambda=1$

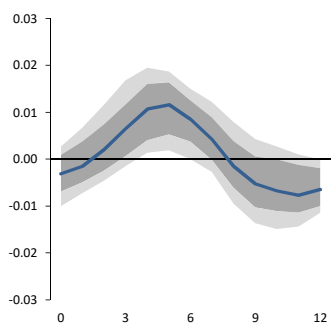

Retail funding

Liquidity
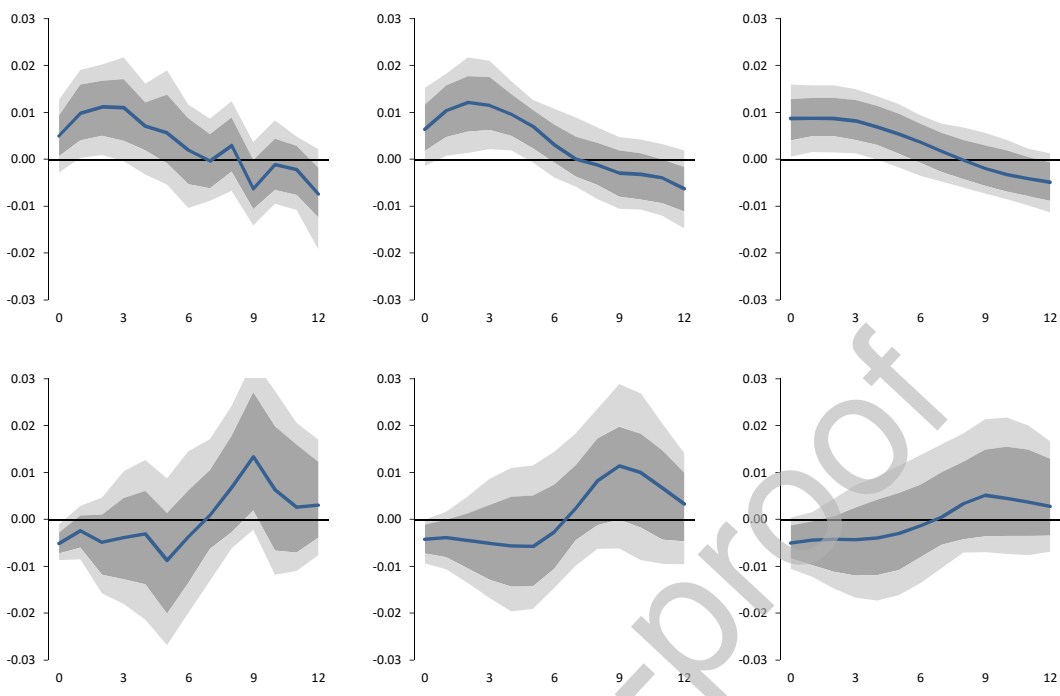
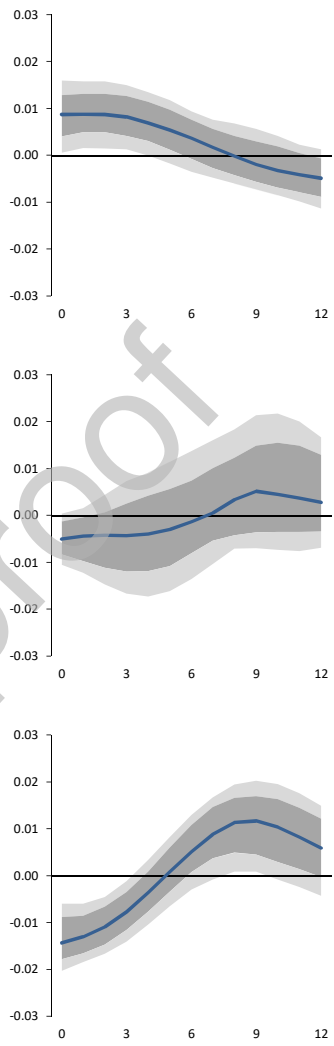

$\lambda=100$
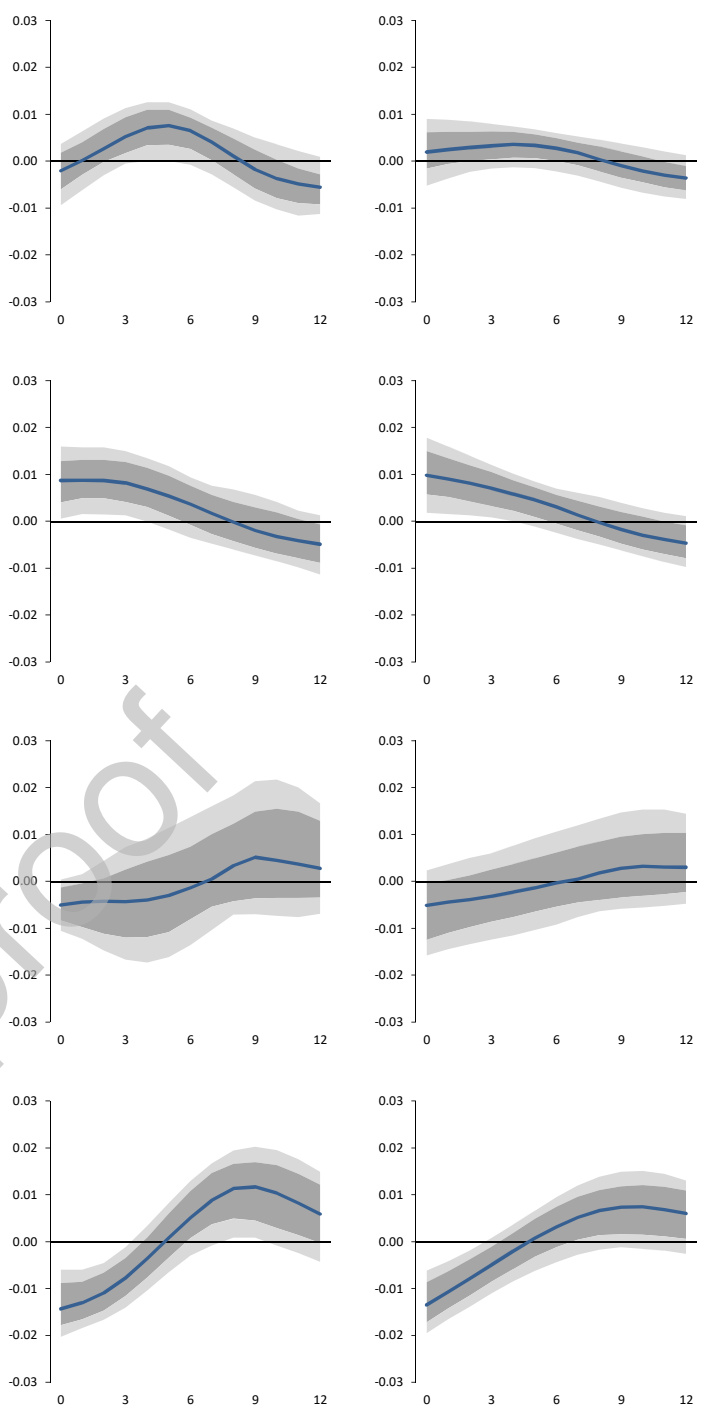

Note: horizon is monthly; 68 and 90 percent bootstrapped credible sets clustered by time and adjusted for persistent common shocks; $\lambda=$ imposed degree of smoothness 


\section{Journal Pre-proof}

\section{Figure A4 - Estimations with dummy for low-capitalized banks: smoothed IRFs for the volume of lending}

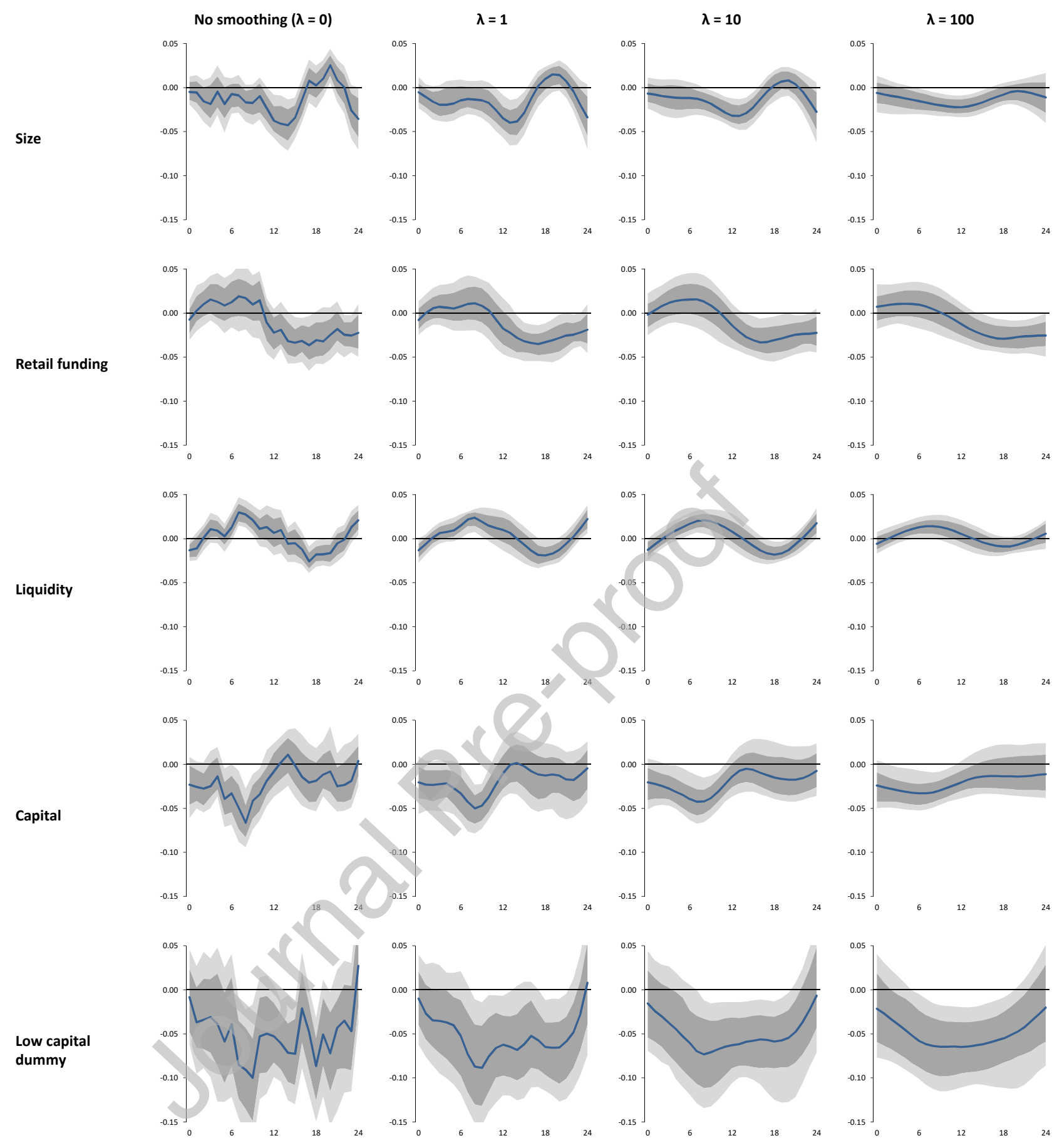

Note: horizon is monthly; 68 and 90 percent bootstrapped credible sets clustered by time and adjusted for persistent common shocks; $\lambda=$ imposed degree of smoothness 
Figure A5 - Estimations with dummy for low-capitalized banks: smoothed IRFs for bank lending rates

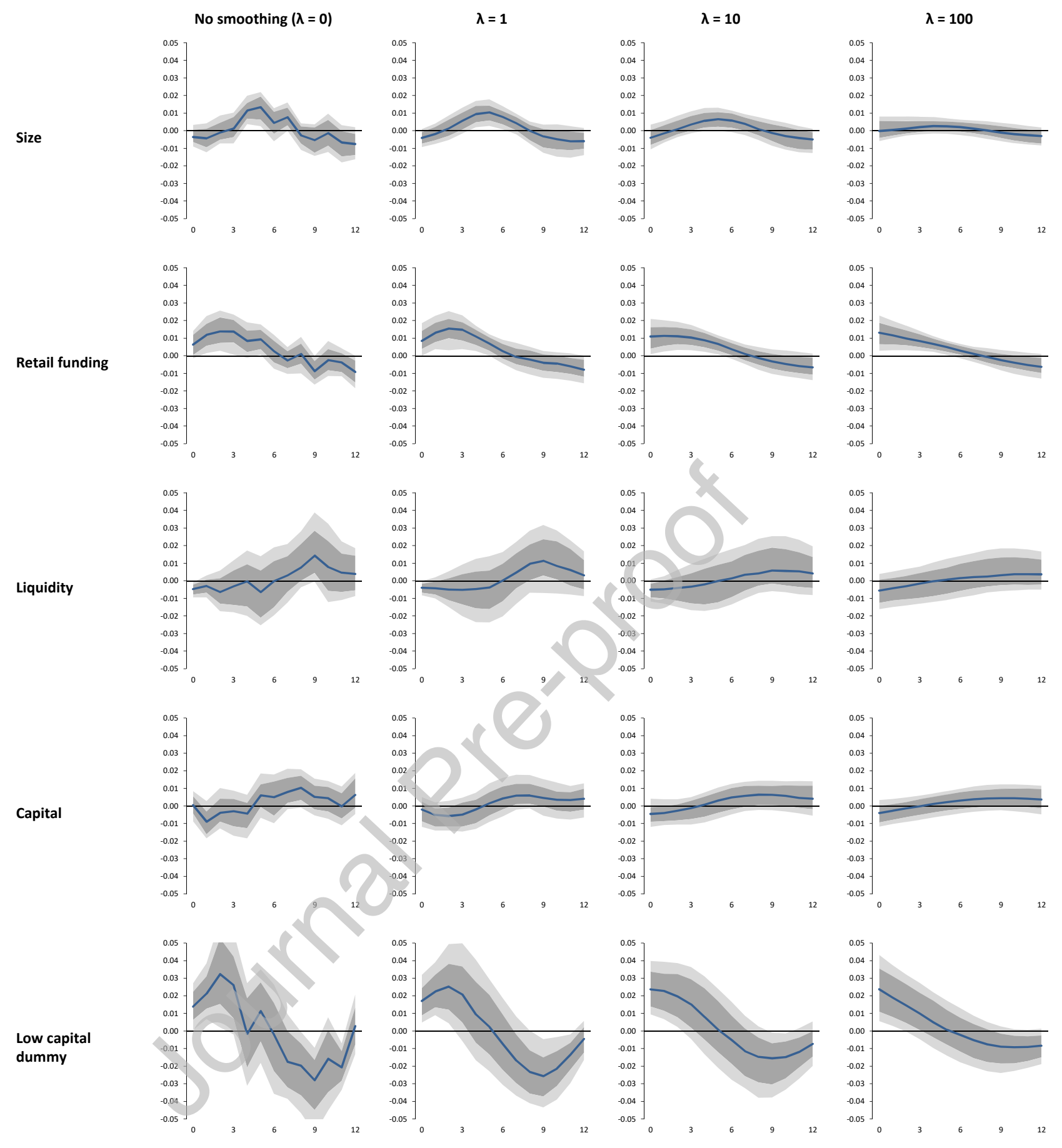

Note: horizon is monthly; 68 and 90 percent bootstrapped credible sets clustered by time and adjusted for persistent common shocks; $\lambda=$ imposed degree of smoothness 


\section{Journal Pre-proof}

Figure A6 - Estimations with interaction effects: smoothed IRFs for the volume of lending

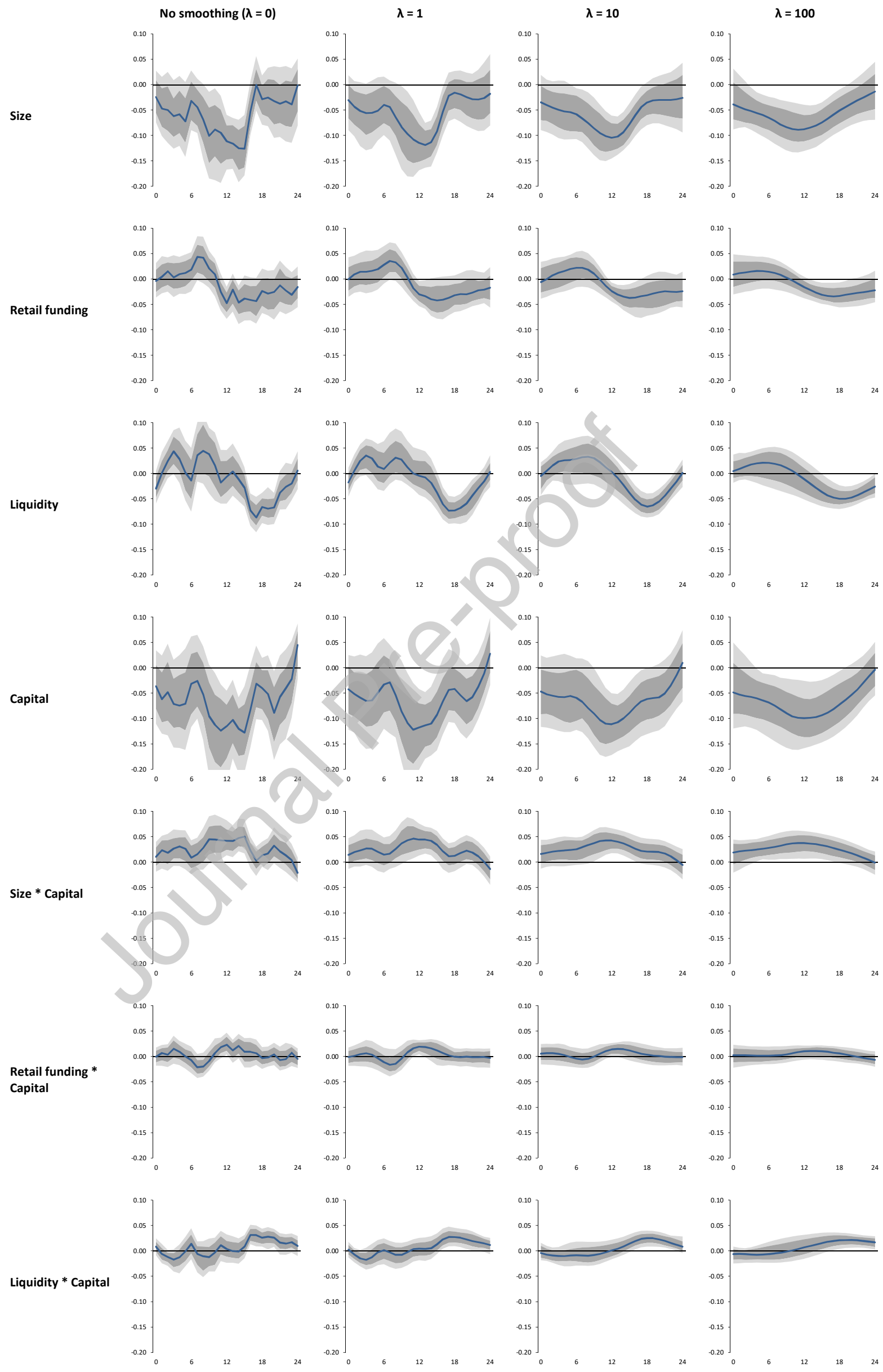


Figure A7 - Estimations with interaction effects: smoothed IRFs for bank lending rates

Size

No smoothing $(\lambda=0)$
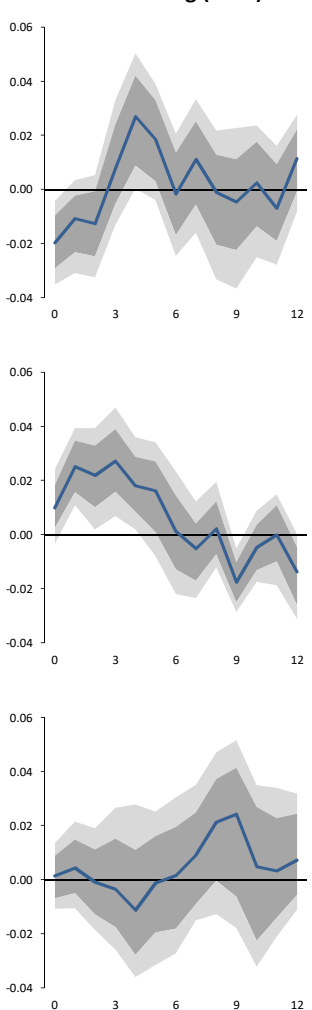

Capital

Size * Capital

Retail funding * Capital
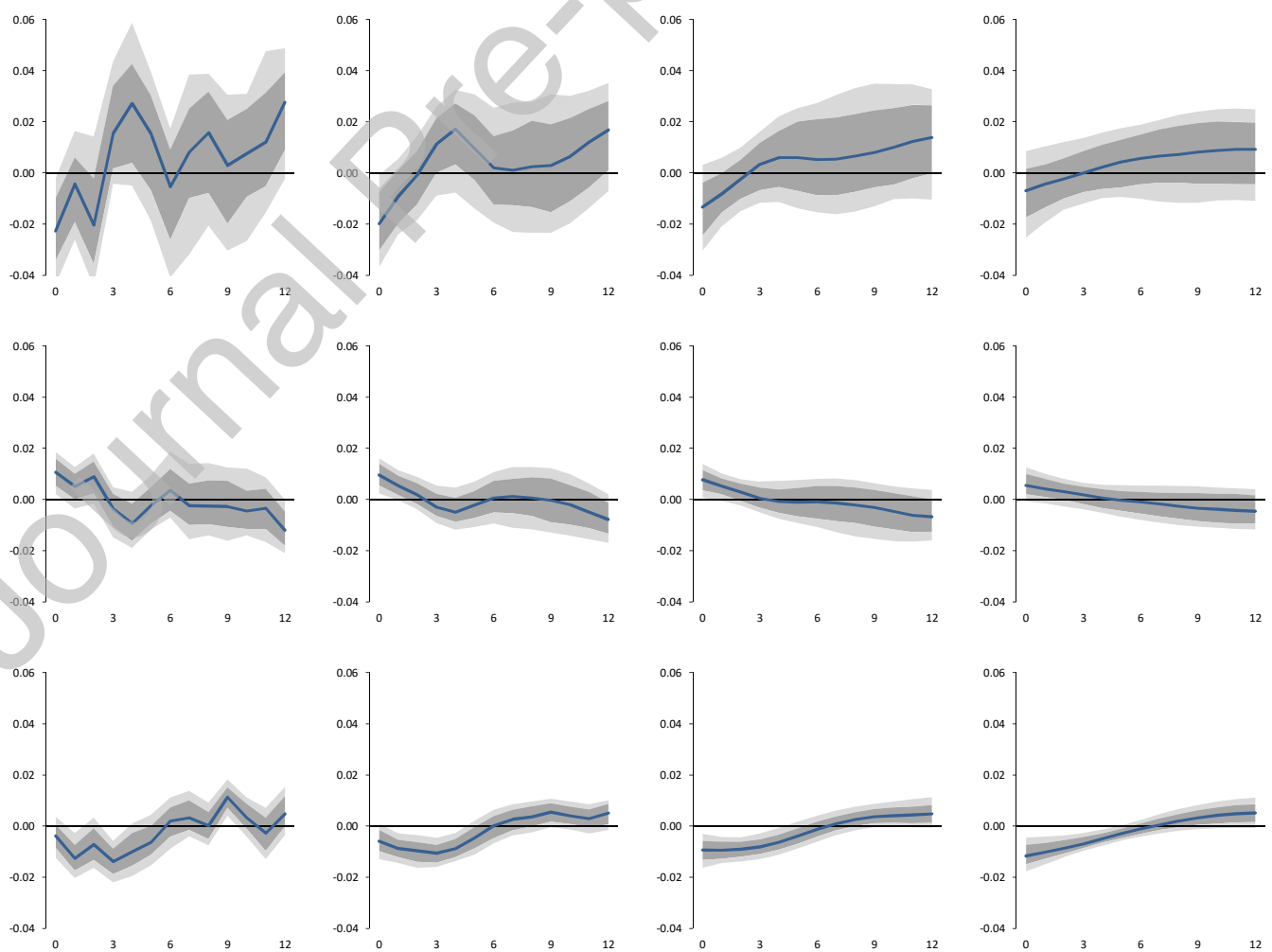

Liquidity * Capital
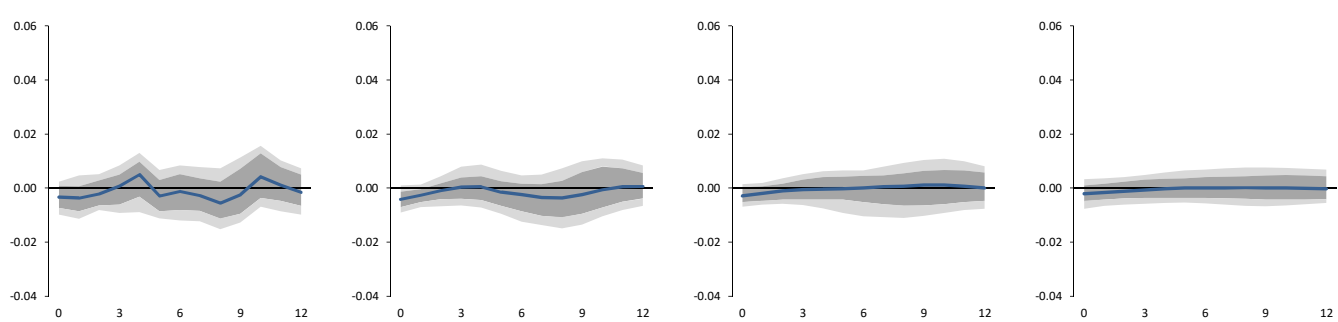

Note: horizon is monthly; 68 and 90 percent bootstrapped credible sets clustered by time and adjusted for persistent common shocks; $\lambda=$ imposed degree of smoothness 